\title{
Toksik Liderliğin Bir Çıktısı Olarak Örgütsel Bağlılık ${ }^{1}$
}

\author{
DOI: 10.26466/opus.599311
}

\author{
Yeşim Eriș ${ }^{*}$ Korhan Arun** \\ * Y.L, Tekirdağ Namık Kemal Üniversitesi İşletme Anabilim Dalı, İşletme Bilim Dalı, Tekirdağ \\ E-Posta: yesimeris57@hotmail.com \\ ORCID: $0000-0002-7877-6840$ \\ **Doç.Dr., Tekirdağ Namık Kemal Üniversitesi, İktisadi ve İdari Bilimler Fakültesi, Tekirdağ \\ E-Posta karun@nku.edu.tr \\ ORCID: $\underline{0000-0001-7494-9591}$ \\ Öz
}

Araştırmada banka çalışanlarının örgütsel bağglllı̆̆ına, toksik liderliğin ve demografik değişkenlerin etkisinin incelenmesi amaçlanmıştır. Bu amaç çerçevesinde; bir kamu bankasında örgütsel bağlılık seviyesi, yöneticilerin toksik liderlik seviyesi, bunlarm birbiriyle ilişkisi ve birbirine olan etkisini demografik özellikler açısından ampirik olarak incelenmiştir. Araştırmanın ifade edilen amaçlarına ulaşmak maksadıyla tarama modeli tercih edilmiştir. Araştırmanın evrenini, Doğu Anadolu Bölgesinde bulunan bulunan bir kamu bankasında görev yapan çalışanlar oluşturmaktadır. Araştırma örneklemini ise evrenden "Basit Tesadüfi Örnekleme" yöntemi kullanılarak seçilen 302 banka çalışanı oluşturmaktadır. Araştırmada banka çalışanlarının toksik liderliğe ilişkin algıları "kurumda görev alınan pozisyon" değişkenine göre "Çıkarcılık" ve "Toksik Liderlik Genel" boyutlarında anlaml farklılık gösterdiği saptanmıştır. Anlaml farklılığın kurumda pozisyonu memur ile üst yetkili; yetkili yardımc-yetkili ile üst yetkili; uzman yardımoss-uzman ile üst yetkili olanlar arasında olduğu saptanmıştır. Banka çalışanlarının örgütsel bağhllı̆̆a ilişkin algıları "cinsiyet ve medeni durum" değiişkenleri açısından anlaml farklılık gösterdiği; "eğitim durumu", "mesleki tecrübe", "kurumda çalışma süresi" ve "kurumdaki pozisyon" değişkenlerine göre ise örgütsel bağlllık genel boyutunda anlamlı farklılığın olduğu belirlenmiştir. Araştırmada, Toksik Liderlik ve Örgütsel Bağhllık arasında negatif yönlü anlamlı bir ilişki olduğu tespit edilmiştir. Araştırmada banka çalışanlarının algılarına göre yöneticilerin toksik liderlik düzeyi arttıkça çalışanların örgütsel bağlllık düzeyi azaltmaktadır. Başka bir ifade ile her iki değişken arasında neden-sonuç ilişkisinin olduğu saptanmıştır.

Anahtar Kelimeler: Örgütsel Bă̆gllık, Toksik Liderlik, Banka Çalışanları, Banka Yöneticileri

\footnotetext{
${ }^{1}$ Bu çalışma Dr. Korhan ARUN'un danışmanlığını yaptığı Yeşim ERiş'in "Toksik Liderliğin Örgütsel Bağlılığa ve Iş Tatminine Etkisi: Bir Kamu Bankası Örneği" tezinden türetilmiştir.
} 


\title{
Organizational Commitment as an Output of Toxic Leadership
}

\begin{abstract}
The aim of this study is to investigate the effect of toxic leadership and demographic variables on organizational commitment of bank employees. For this purpose, level of organizational commitment in a public bank, the level of harmful leadership of managers, their interrelation, and their interrelation were examined empirically in terms of demographic characteristics. In order to reach the stated aims of the study, screening model was preferred. The population of the study is composed of employees working in a public bank located in Eastern Anatolia Region. The research sample consisted of 302 bank employees selected from the universe using the "Simple Random Sampling" method. In the study, the perceptions of the bank employees regarding toxic leadership were found to differ significantly according to the" position in the institution" and in the "Narcissim" and "Toxic Leadership General" dimensions. The position in the institution of the meaningful difference is the officer with the top authority; authorized-competent and highest authorized; It is among the top authorized persons with expert. The employees' perceptions of organizational commitment differed significantly in terms of gender and marital status; It was determined that there was a consequential difference in general dimension of organizational commitment according to education status, professional experience, working time in institution and position in institution. In the study, a relevant negative correlation was found between Toxic Leadership and Organizational Commitment. According to the perceptions of bank employees, the level of organizational leadership of employees decreases as the level of toxic leadership of manager's increases. In other words, it was found that there was a cause-effect relationship between the two variables.
\end{abstract}

Keywords: Organizational Commitment, Toxic Leadership, Bank Employees, Bank Managers 


\section{Giriş}

İş dünyasında rekabet koşullarının artmasıyla birlikte bir işletmenin en önemli kaynaklarından biri olan insana yönelik uygulamalar, o işletmenin etkinliğinin sağlanabilmesi açısından dikkate alınması gereken önemli bir konudur (Brown, 2014; Şimşek, 2008). Bu etkinliğin sağlanmasında, yönetsel üslup ve kültür, örgütsel stratejide en kritik faktörleri oluşturur (Brown, 2014). Buna bağlı olarak, liderlik örgütsel bağlılığın en önemli öncüllerinden biri olarak literatürde yer almaktadır (Morrow, 2011). Bu önemden dolayı olumlu ve olumsuz her açıdan incelenmesi gereklidir ve liderler yalnızca bireysel olarak kendi kendilerini tahrip edici değil ayn zamanda liderlik ettikleri kurum ve topluluklar için örgütsel bağlılığ1 etkileyebilecek durumda bulunabilirler(Kramer ve Gavrieli, 2005). Bu olumsuz yönetim boyutlarından, yönetsel toksisite sorunu çok uzun bir geçmişe sahip olsa da, sonuçlarının hem bireye hem de kuruma zararlı olduğu ancak son zamanlarda ortaya çıkarılmıştır(Wright, 2015).

Liderin, toplum konumundaki itibarı, o kişinin topluluk kararlarına katılım derecesi ile değil; liderlerinin nüfuzunun itibarı ile çok fazla ilişkilidir(Breiger, 2002). Lakin bu gücün kullanım zamanla olumsuz bir hal alabilir. Yakın zamanda liderliğin olumsuz tarafları araştırmacıların ilgisini çekmiş ve birçok araştırmanın konusu olmuştur. Baz çalışmalarda "yıkıcı liderlik", (Woestman \& Wasonga, 2015), "kötü davranan liderlik" (Tepper, 2007), "narsist liderlik" (Paunonen ve diğerleri, 2006), "zorbalık" (Ferris ve diğerleri, 2007; Harvey ve diğerleri, 2007) ve "toksik liderlik" (WilsonStarks, 2003; Williams, 2005; Dobbs, 2014) kavramları analiz edilmiştir. Bu kavramlar genel itibariyle çeşitli yazarlar tarafından; liderin çalışanlarına karşı düşmanlığını, kişilerarası ilişkilerde etkilerini ve örgütün çıarlarına zarar verme durumlarını açıklamak için kullanılmıştır (Dobbs, 2014). Yani bir lider, İşin kalitesini, moralini ve hatta bir kurumun istikrarını bozan davranış ve eylemler sergiliyorsa (Wright, 2015) toksik olarak adlandırılabilir. Toksik yönetim tarzının etkileri, bir bireyin sağlığı üzerindeki zararlı etkilerinden kuruluşun finansal hedeflerini olumsuz yönde etkilemeye kadar geniş bir aralıkta olabilir (Futterman, 2004). Algılanan liderlik davranışları başta örgütsel bağlllık olmak üzere birçok örgütsel değişken üzerinde etkilidir (Davis ve Rothstein, 2006).Aşağıda da 
açıklanacağı şekilde örgütsel bağlllıkta toksik liderlikten etkilenen bu kavramlardan biridir (Aryee, Chen, Sun, ve Debrah, 2007).

Çalışan bireylerin sadece görevlerini yapmaktan ziyade, kendilerini, çalıştıkları kurumla bütünleştirmeleri önemli bir husustur. Bu bütünleşmenin bulunmaması psikolojik anlamda çalışanların, kuruma dair verimlilik ekseninde hizmet vermelerini engellemektedir. $\mathrm{Bu}$ şekilde değerlendirildiğinde örgütsel bağlılık, bir örgüt ile çalışanı arasında söz konusu olan iş akdinin geçen zaman içerisinde, karşılıklı etkileşim neticesinde manevi bir değere erişmesi ve böylelikle de çalışan bireylerin kendi çıarlarından ziyade toplu olarak çıkarlara odaklanmaları, bunun ötesinde de örgütlerinin çıkarlarını kendilerininkinden çok daha önemli görmeleri adına, bir fedakârlık odaklı olarak hareket etmelerinin yolunu açan bir duygu ve davranış biçimidir (Bozkurt ve Yurt, 2013). Fakat sadece örgütsel bağlılığın sonuçlarına odaklanma iki takım soruna yol açar. Birincisi, örgütsel bağlllık bazen bağımsız olarak ölçülebilen (ya da olmayan) bir yapı olarak düşünülmesi ya da bazen iş ya da kariyer memnuniyeti gibi diğerleriyle yüksek derecede ilişkili bir kavram olarak kabul edilmesidir. Bu yanlış anlaşılmaların önlenmesi açısından bu çalışmada örgütsel bağlılık daha nitel ve işlemsel (sürece dayalı) olarak kabul edilmiş ve "bireylerin kendi değerlerinin ve hedeflerinin organizasyonla uyuşma derecesini düşündüğü bir düşünce seti " olarak tanımlanmıştır (Alatrista ve Arrowsmith, 2004; Mowday, Porter, ve Steers, 1982). Bu şekildeki durumsal ve dinamik örgütsel bağlllık yaklaşımının faydası, liderler gibi bağllı̆̆ etkileyen diğer odakların da önemli olduğunu vurgulamaktır. Literatürde bağlılık odakları "foci of commitment" olarak adlandırılan bu yaklaşım liderlerin, demografik değişken ve kişisel özelliklerin de örgütsel bağlllık üzerinde etkili olduğunu vurgulamaktadir(Alatrista ve Arrowsmith, 2004; Gregersen, 1993; Mowday et al., 1982) (O’Neill vd., 2009, s.26).

Bu etkenlerden algılanan lider desteği arttıkça, örgütsel bağllık düzeyi de yükselmektedir. Çünkü liderler, örgütün bir nevi temsilcileri ve vekilleridir. Sosyal etkileşim kuramı çerçevesinde liderin desteğiyle karşılaşan işgörenler, temin ettikleri bu tip faydaların da örgütten geldiğini düşünerek, bunun karşllı̆ında örgüte duygusal biçimde bağlanacak ve gönüllü biçimde mevcut işlerine devam edeceklerdir (Casper vd., 2011, s.648; Yang, 2012, s.35). Başka bir deyişle, örgütsel özellikler, çalışanların 
bağlılığını daha doğrudan etkileyen belirli lider davranışlarını geliştirebilecek veya kolaylaştırabilecek grup ilişkilerinin niteliği gibi çalışanlar üzerinde daha proksimal etkiler oluşturmak için gerekli ortamdan başka bir şey değildir (Mathieu ve Zajac, 1990).

Yukarıda paragrafta belirtildiği gibi liderin davranışları çalışanların örgütsel bağllığını etkilemektedir. Bu kapsamda araştırmada liderlik türlerinden toksik liderlik ele alınmıştır. Toksik liderliğin çalışanların örgütsel bağlılığını banka çalışanlarının algıları doğrultusunda ilişkisini, etkisini ve düzeyini belirlemek araştırma kapsamında problem olarak belirlenmiştir.

\section{Toksik Liderlik}

Liderlik davranışları genel olarak birbirlerine benzerlik gösterseler de bazı liderlik uygulamaları arasında, hâkimiyet kurma ve baskı yaratma açısından farklılıklar söz konusudur. Öte yandan liderlik, genel olarak bir bireyin diğerleri üzerinde elinde bulundurduğu veya sahip olduğu özellikler sayesinde, bir baskı kurma düşüncesini ön plana çıkarılabilmektedir. Fakat toksik liderlik gibi liderlik türleri, çevreleri üzerinde baskı kurma konusunda çok daha baskın ve sert uygulamalara, davranışlara ve imaja sahip olmaktadırlar. Bu açıdan bakılacak olursa toksik liderliği farklı kılan özellikleri, onu diğer olumsuz içerikli liderlik davranışlarına göre farklı kılmaktadır.

Temel olarak bakıldığında, toksik liderliğin özelliklerini şu şekilde sıralamak mümkündür (İzgüden, Eroymak ve Erdem, 2016; Wright, 2015):

- Bireysel olarak liderin yüceltilmesi, liderin çevresinin fazlasıyla aşağılanması,

- Astların mikro yönetimi,

- Cehalet ve beceriksizlik,

- Liderin, sürekli olarak ihtişama dayalı olarak değerlendirilmesi ve yaptığı her ne olursa olsun, olumlu olarak ele alınması ve buna bağlı olarak kibir,

- Zaman içerisinde önce liderden, daha sonra birbirlerinden, en sonunda da örgütten kopmalarına sebebiyet verilmesi,

- Korku ve korkuya dayalı yönetim. 
Bazen toksik liderlik davranışları kişilik bozukluğundan kaynaklanan yönetici uygulamasıyla (Futterman, 2004) karıştırılsa bile, liderlik davranışlarının toksik olması için bilinçli ve karşı tarafa zarar verici yönde olması gerekmektedir. Henrich'in (2016) tarafından ifade edildiği üzere, toksik liderliğin özellikleri bazında konu ele alındığında, sürecin toksik liderin çıarlarına fazlasıyla odaklı olduğu görülmektedir. Buna göre toksik liderler, eğer bir başarı elde edilecekse bile bunun kendi himayeleri altında olmasını, başarının olumlu yansımalarının kendileri üzerinde olmasını ve bununla birlikte de sadece kendilerinin başarılı olarak addedilmesini beklemektedirler. Bunun ötesinde, eğer bir başarıdan söz edilecekse, bu başarının varlığı eğer ki lider ve çevresi ile paylaşılacaksa toksik liderler söz konusu başarının engellenmesi adına ellerinden geleni yapmakta ve süreci sabote edebilmektedirler. Hatta bu noktada toksik liderler, örgütsel anlamda elde edilebilecek bir başarının ortadan kaldırılmasını ve örgütün zor zamanlar geçirmesini dahi göze almaktadırlar. Bu noktada toksik liderliğin, kişiselleştirilmiş yapısının ve bunun genel olarak yansımalarının da bir örneğine rastlanmaktadır; eğer süreç toksik liderin himayesinde değilse sürece dair tüm emeğin göz ardı edilmesi ve ortadan kaldırılması meşrudur (akt. Vreja, Balan ve Bosca, 2016).

Geniş ölçekli olarak ele alındığında Lipman-Blumen toksik liderlik davranışlarını aşağıdaki davranış unsurları ile ele almaktadır (LipmanBlumen, 2010):

- Fikir beyanına şiddetle karşı çıkmak ve bunu engellemeye çalışmak,

- Herhangi bir eleştiriyi, zarar verecek şekilde bastırmaya çalışmak,

- Çözüm odaklı teşhisleri sert bir biçimde geçersiz kılmaya çalışmak,

- Kuralları, normları, örgütsel kültürü ve önceden belirlenmiş sınırları hiçe sayarak, yapıyı ve süreci sadece liderin isteklerine ve beklentilerine göre şekillendirmek,

- Rakiplerin elimine edilmesini, yerini alabilecek bireyin işlerini zorlaştırmaya çalışmak,

- Totaliter rejim inşa etmeye çalışmak,

- Çevresindekilerini, örgüt dişındaki çevreyi olumsuz yönde etkileyecek ve liderin örgütünün çıkarlarına ters olacak birey ve grupları mümkün olduğunca bertaraf edebilmek adına eğitmek,

- İtaat kabiliyeti olmayan astları sürecin dişına itmek, 
- Yapının çöküşüne ve sistemin içerisindeki gerginliğin tırmanmasına sebebiyet verecek olsa dahi mutlak olarak eldeki liderlik gücünü, çevreyi bertaraf etme pahasına korumak,

- İzleyenleri susturmak ya da sürecin dişına itmek,

- Hataları kişisel duyguların tatmini olarak kullanmak ve görmezden gelmek,

- Belirsizlikler üzerinden bir sistem oluşturarak örgütün ve çevrenin zarar görmesini göz ardı etmek.

Liderlik davranış yelpazesinin diğer bir ucu olan laissez-faire (Yukl, 2013) diğer bir adıyla serbest liderlik davranışları da toksik bir yönetim ortamı oluşmasına neden olabilmektedir (Wright, 2015). Çünkü bazı yazarlar tarafindan bu tip liderlik etkin olmayan hatta liderlik olmayan bir yönetim tarzı olarak görülür (Tubbs, 2012).

Yukarıda sıralanan noktalara bakıldığında, bir toksik liderin, mümkün olduğunca, belirsizliklerden, sorunlardan ve olumsuzluklardan beslendiği, buna istinaden de kendisine uygun bir düzen yaratmaya çalıştığ görülmektedir. Buna göre toksik liderler, başarının varlığı olsa bile bunun kaostan ortaya çıkmasına ve başarıyı yaratacak ekibin tıpkı kendileri gibi düşüncelerini yansıtmalarına uğraşmaktadırlar. Bunun için de mümkün olduğunca sert ve net uygulamaların söz konusu olduğu, uyumsuzluk gösteren bireylerin dışlandığı, aşağılandığı ve sürecin dışına itildiği, nihayetinde de toksik liderlerin kendilerine uygun ilerlemeyen bir düzeni, başarı getirme ihtimali son derece yüksek olsa da anlık olarak ortadan kaldırmaya düşüncesine sahip oldukları görülmektedir. Bu sebeple de toksik liderlerin bu yukarıda sıralanan karakteristik davranışları, mümkün olduğunca zarar vermeye yönelik olarak algilanabilecektir.

\section{Örgütsel Bağlılık}

Örgütsel bağlllık, işletmeye sadakat ve bağlllık derecesinin göstergesidir (Iverson ve Deery, 1997, s.73). Bağlılık, örgüte duygusal olarak bağlanma ya da manevi anlamda tutunmayı temsil eder. Öyle ki kuruma olan bağı güçlü olan işgörenler, örgütün üyesi olmaktan zevk alarak örgütle özdeşleşerek ve kendini vazifelerine verebilmektedir (Allen ve Meyer, 1990, s.2). Dolayısıyla örgütsel bağlılık; örgütsel hedef ve değerlere sıkı sıkıya sahiplenmek, kayda değer düzeyde örgütün lehine çaba göstermek ve örgütün üyesi olarak 
çalışma yaşamını sürdürmeyi arzulamaktır (Wong vd. 2001, s.329). Öte yandan örgüte duygusal biçimde bağlanıldığı gibi, mesleğe, iş grubuna, çalışma arkadaşlarına veya sendikaya bağlılıktan da söz edilebilir (Cohen, 2007, s.350).

Fenomenolojik yaklaşımda, olay, ve olayların nasıl belirlendiğinin takdir edilmesi; her zaman göründükleri bağlamla ilgilidir(Holt ve Sandberg, 2011). Bu felsefik organizasyon kuramına göre örgütsel bağlllı̆̆ içinde bulunduğu örgütsel ortamdan ayrı düşünmek uygun değildir. Bu duruma karşılık belirli bir işletmede çalışan işgörenlerin bağlllıklarına etki eden değişken, o işletmede çalışanların algıladıkları liderliktir.

Liderlik dahil örgütsel bağlllığın öncülleri olan birçok çevresel değişken bulunmaktadır(Choi, Oh, ve Colbert, 2015). Bununla birlikte liderlik, örgütsel adalet üzerinde doğrudan etki eden bir etmen olmakla birlikte, diğer öncülleri de etkileyebilecek bir etmen olarak karşımıza çımaktadır(Mathieu ve Zajac, 1990). Örgütsel adalet (Colquitt, Conlon, Wesson, Porter, ve Ng, 2001), güven (Dirks ve Ferrin, 2002), destek ve güçlendirme (Chiaburu, Oh, Berry, Li, ve Gardner, 2011), algilanan destek (Okun, 2020; Rhoades ve Eisenberger, 2002) gibi durumsal değişkenler doğrudan liderlik uygulamalarıyla etkilidir. Bununla birlikte ilginç olarak bu değişkenlerin genelde olumlu etkisine bakılmış, liderlerin çalışan ve örgüt aleyhine olan olumsuz etkilerine bakılmamıştır.

Çalıştı̆̆ kurumu terk etme olasılığı en düşük olanlar, örgütle bağı en kuvvetli olup, bu tutkuyu tutarlı biçimde sergileyenlerdir (Allen ve Meyer, 1990: 1; Cuskelly ve Boag, 2001, s.82). Başka bir ifadeyle örgütsel bağlllık düzeyi azalırsa, işten ayrılma eğilimi de artacaktır (Kim vd., 2005, s.175). Bireyler, örgüte üye olmalarından itibaren bağlılık düzeyleri karşılaştıkları durumlara ve beklentilerine göre zamanla değişerek artmakta ya da azalmaktadır. Rusbult ve Farrel (1983'den akt. Gül, 2002, s.38) örgütsel bağlılığı, işten tatmin olunmasa bile işe tutkuyla bağlı kalmak şeklinde tanımlamıştır. Bu durumda işgörenlerde doyum düşük olsa diğer bir deyişle toksik liderlik etkisinde bile örgütsel bağlılığın değişmeyebileceği varsayımından bahsedilebilir.

Toksik liderliğin çalışanlar üzerindeki kontrol davranışları örgütsel bağlılığı etkileyen diğer bir unsurdur. Çalışanlar, iş ve faaliyetlerinde ne kadar çok kontrol yetkisine sahip olursa, örgütlerine o kadar çok 
bağlanmaktadırlar (Raghunathan vd., 1998, s.577). Bu durumda toksik liderliğin örgütsel bağlıllğı azaltacağı varsayımında bulunulabilir.

Bağlığın çeşitleri ve derecesi ise toplumsal ve örgütsel kültürlere göre değişebilmektedir (Chang vd., 2007, s.365). Diğer yandan işe girmeden önce normatif bağlllığın etkisinden söz edilirken; işe girmeyi müteakip verilen ödüller, kazanılan statü ve şöhret gibi unsurların derecesi yükseldikçe, başka bir deyişle karşılıklı etkileşim ve alışveriş miktarı arttıkça, bağlılık duygusal şekle dönüşmekte ve gittikçe içselleştirilmektedir. Bu uygulamalar da örgütsel kültüre göre değiştiğinden örgütsel bağlllı̆ğ örgüt kültürü bağlamından ayrı olarak düşünmek uygun değildir. Buna karşın genelde yapılan çalışmalar farklı işletme veya iş gruplarını kapsamakta bu bakımdan kültürün etkisi gözardı edilmiş olmaktadır.

Çalışma yaşam kalitesinin alt bileşenlerinden olan adil ücretlendirme, terfi olanakları, kişisel becerilerin geliştirilmesine imkân sağlayan eğitim ve geliştirme programları ile iyi bir performans değerlendirme sistemi, işgörenlerin örgüte olan bağlllıklarını pekiştirmektedir (Salleh vd., 2012, s.706). Çalışanlarına yetki ve özerklik verme de örgütsel bağlllı̆̆1 besleyen etkenler arasındadır (Erdem, vd. 2015; Chen ve Aryee, 2007, s.233). Çünkü çalışanlar, yaptıkları işle ilgili kendilerine inisiyatif verildiğinde, çalışma şeklini kendileri belirleyebilmektedir. Bununla birlikte kurumun kendilerine güven duyduğunu ve değer verdiğini hisseden işgörenler, duygusal olarak örgütle bağlarını güçlendirmekte ve bağlılıklarını gösterme ihtiyacını güçlü biçimde hissetmektedir (Miao vd., 2013, s.3275).

\section{Araştırmanın Amacı}

Araştırmada banka çalışanlarının örgütsel bağlılığını, yöneticilerin toksik liderlik özellikleri ve çeşitli değişkenler (demografik özellikler) açısından incelemek amaçlanmıştır. $\mathrm{Bu}$ amaç çerçevesinde banka çalışanlarının örgütsel bağlllık, yöneticilerin toksik liderlik seviyesini, bunların birbiriyle ilişkisini, birbirine olan etkisini çeşitli değişkenler (demografik özellikler) açısından belirlemek amaçlanmıştır. Bu amaçlar doğrultusunda araştırmada şu sorulara yanıt aranmıştır:

1) Bankada görev yapan çalışanların örgütsel bağlllıkları algıları hangi seviyededir? 
2) Bankada görev yapan çalışanların toksik liderlik algıları hangi seviyededir?

3) Bankada görev yapan çalışanların örgütsel bağlllığa ilişkin görüşleri arasında cinsiyet, medeni durum, eğitim durumu, mesleki tecrübe, bulunduğu kurumda çalışma süresi ve kurumda görev alınan pozisyon değişkenlerine göre anlamlı farklılık var mıdır?

4) Bankada görev yapan çalışanların toksik liderliğe ilişkin algıları cinsiyet, medeni durum, eğitim durumu, mesleki tecrübe, bulunduğu kurumda çalışma süresi ve kurumda görev alınan pozisyon değişkenlerine göre anlamlı farklılık göstermekte midir?

5) Bankada görev yapan çalışanların örgütsel bağlllık ve toksik liderlik algıları arasında ilişki var mıdır? Varsa hangi düzeyde ve yöndedir?

6) Bankada görev yapan çalışanların örgütsel bağllı̆̆ına yöneticilerinin göstermiş olduğu toksik liderlik davranışları etki etmekte midir?

Bu sorulara istinaden araştırmanın hipotezi aşağıdaki gibidir:

- H1: Toksik liderlik davranışları örgütsel bağlılık üzerinde olumsuz yönde etkilidir.

\section{Yöntem}

Yöntem kısmında araştırma tasarımı, soruları ve anket seçimi, araştırmanın modeli, evreni, örneklemi, verilerin toplanması ve toplanan verileri çözümleme tekniklerine ilişkin bilgiler verilecektir.

\section{Araştırmanın Modeli}

Araştırmada tarama modeli tercih edilmiştir. Tarama modeli, bir örneklemdeki bireylerin bir ve birden fazla değişkene göre nasıl dağılım gösterdiğini belirlemek maksadıyla kullanılmaktadır. Tarama modeli kullanılan araştırmalarda evrenin tamamından veri toplamak yerine, evrenin belirli bir bölümünden yani belirli bir örneklemden veri toplanabilmektedir (Fraenkel ve Wallen, 2006; akt. Büyüköztürk ve diğerleri, 2012). 


\section{Araştırmanın Evreni ve Örneklemi}

Araştırmanın evrenini, Doğu Anadolu Bölgesinde bulunan bir kamu bankasında görev yapan banka çalışanları oluşturmaktadır. Araştırma örneklemini ise evrenden "Basit Tesadüfi Örnekleme" yöntemi kullanılarak belirlenen 302 kişi oluşturmaktadır. Basit Tesadüfi Örnekleme türünde, evrendeki tüm katılımcların birbirine göre eşit seçilme şansına sahip oldukları örnekleme türüdür (Karasar, 2016).

Araştırmaya katılan banka çalışanlarının \%42,4'ünün kadın (128), \%57,6'sının ise erkek (174); \%66,6'sının evli (201), \%33,4'ünün ise bekâr (101); \%7,6'sının lise ve ön lisans (23), \%81,8'inin lisans (247) ve \%10,6'sının lisansüstü (32) eğitim mezunu; \%37,1'inin 5 yıl ve altı (112), \%38,1'ünün 6-10 yıl (115), \%24,8'inin 10 yıl ve üstü (75) mesleki tecrübeye sahip; \%41,1'inin 5 yıl ve altı (124), \%37,4'ünün 6-10 yıl (113), \%21,5'i ise 10 yıl ve üstü sürede (65) bulundukları kurumda çalıştıkları; \%33,4'ünün Memur (101), \%46,4'ünün Yetkili Yardımci-Yetkili (140), \%6,6's1 Üst Yetkili (20), \%8,3'ünün Uzman Yardımcısı-Uzman (25), \%5,3'ü ise Müdür Yardımcısı (16) olarak kurumda görev yapmaktadırlar.

\section{Veri Toplama Araçları}

Araştırma verilerini toplamak için "Toksik Liderlik" ve "Örgütsel Bağlllık" ölçekleri kullanılmıştır. Araştırmada kullanılan Örgütsel Bağllık ve Toksik Liderlik ölçekleri, “(1) Hiç Katılmıyorum, (2) Katılmıyorum, (3) Orta Düzeyde Katılıyorum, (4) Katılıyorum ve (5) Tamamen Katılıyorum" şeklinde beşli likert tipi ölçek formatına uygun olarak hazırlanmıştır.

\section{Toksik Liderlik Ölçeği}

Ölçek Çelebi, Güner ve Yıldız (2015) tarafından geliştirilmiştir. Ölçeğin orijinal formu, toplam 30 maddeden ve "Çıkarcllı", "Değer Bilmezlik", "Olumsuz Ruhsal Durum", "Bencillik" olmak üzere 4 boyuttan oluşmaktadır.

Ölçeğin Çelebi, Güner ve Yıldız (2015) tarafından yapılan güvenirlik çalışması sonucu iç tutarlık katsayısı " $\alpha=, 96$ " olarak bulunmuştur. Yapılan 
çalışmada ise iç tutarlık katsayısı " $\alpha=, 98$ " olarak bulunmuştur. Yapılan çalışma ve ölçeğin orijinal formunun Cronbach alfa güvenirlik katsayıları $\alpha>80$ olduğundan kullanılan ölçeğin güvenilirliğinin yüksek olduğu söylenebilir (Kalaycı, 2010).

Yapılan çalışmada kullanılan verilerin faktör analizine uygunluğunu için yapılan analizler sonucunda KMO değeri ,950 ve Bartlett testine ilişkin $\chi 2$ değeri 12307,491 $(p=, 00)$ olarak hesaplanmıştır. Bu değerler, değişkenler arasında iyi düzeyde korelasyon $(\mathrm{KMO} \geq 0,7)$ olduğunu ortaya koymaktadır (Can, 2016). Elde edilen bu değerlerin faktör analizi yapmak için gerekli ölçütleri karşıladığı söylenebilir. Faktörlerin açıkladığı toplam varyans \% 82,05'tir.

Ölçeğin normallik testi için yapılan analizler neticesinde Skewness değeri ,444 Kurtosis değeri -,473 olduğu tespit edilmiştir. Elde edilen Skewness ve Kurtosis değerleri $+1,5$ ve $-1,5$ aralığında olduğundan ölçeğin maddelerinin normal dağıldığı söylenebilir (Tabachnick ve Fidell, 2013).

\section{Örgütsel Bağhllık Ölçeği}

Araştırmada banka çalışanlarının örgütsel bağlılık algısını ölçmek için Meyer ve Allen'ın 1990 ve 1991 yıllarında örgütsel bağlılığın üç bileşenli modelini ele alarak geliştirdikleri örgütsel bağlllık ölçeğinin Meyer ve arkadaşları tarafından 1993 yılında revize edilmiş 18 maddelik formu kullanılmıştır. Ölçek örgütsel bağl1lığı, literatürde de sıkça rastladığımız gibi 3 boyutta ele almıştır. Bunlar; duygusal bağlılık, devam bağlılık ve normatif bağllilıtır.

Yapılan araştırmada, örgütsel bağlllık ölçeğinin güvenirliğinin tespit edilmesinde Cronbach $\alpha$ değeri kullanılmıştır. Ölçeğin Eğilmezkol (2011) tarafından yapılan güvenirlik çalışması neticesinde " $\alpha=0,83$ ” olarak bulunmuştur. Yapılan çalışmada ise " $\alpha=0,81$ " olarak bulunmuştur. Güvenirlik katsayıları $\alpha>.80$ olduğundan kullanılan ölçeğin oldukça güvenilir olduğu söylenebilir (Kalayc1, 2010).

Yapılan çalışmada kullanılan verilerin faktör analizine uygunluğunu için yapılan analizler sonucunda KMO değeri 0,847 ve Bartlett testine ilişkin $\chi 2$ değeri 2397,282 ( $p=0,000)$ olarak hesaplanmıştır. Bu değerler, değişkenler arasında iyi düzeyde korelasyon (KMO $\geq 0,7)$ olduğunu göstermektedir (Can, 2016). Faktörlerin açıkladığı toplam varyans \% 63,203'tir. 
Ölçek maddelerinin normal dağılıp dağılmadığına belirlemek için yapılan analizler sonucunda Skewness değeri -0,074, Kurtosis değeri 0,986 olduğu belirlenmiştir. Bu değerler $\pm 1,5$ aralığında olmasından dolayı ölçek maddelerinin normal dağılım gösterdiği ifade edilebilir (Tabachnick ve Fidell, 2013).

\section{Verilerin Analizi}

Araştırmada verilerin analizi için toplanan veriler SPSS 25 paket programına işlenmiş ve analiz edilmiştir. Araştırmada kullanılan Toksik Liderlik Ölçeği ve Örgütsel Bağlllık Ölçekleri vasıtasıyla toplanan dataların analizinde araştırmanın alt problemleri dikkate alınarak betimsel ve çıkarımsal istatistiki yöntemler kullanılmıştır. Betimsel istatistik için yüzde, aritmetik ortalama ve standart sapma hesaplamaları yapılmıştır. Çıkarımsal istatistik için ise cinsiyet ve medeni durum değişkenleri için "Bağımsız Örneklemler t-Testi", eğitim durumu, mesleki tecrübe, bulunduğu kurumda çalışma süresi, kurumdaki pozisyon değişkenleri için ise "Tek Yönlü Varyans Analizi (ANOVA)" testleri kullanılmıştır. Ayrıca araştırmada, çalışanların örgütsel bağlılığı ve yöneticilerin toksik liderlik özellikleri arasındaki ilişkiyi belirlemek için korelasyon katsayısına, çalışanların örgütsel bağllı̆̆g toksik liderliğin etkileme düzeyini belirlemek için ise basit doğrusal regresyon analizi yapılmıştır.

\section{Bulgular}

Araştırmada veri toplama araçları ile elde edilen verilerin analiz edilmesiyle elde edilen bulgular bu bölümde detaylı bir şekilde araştırmanın alt problemlerinin veriliş sırasına göre anlatılmıştır.

\section{Banka Çalışanlarının Toksik Liderlik ve İş Tatminine İlişkin Algılan}

Bankada görev yapan çalışanların örgütsel bağlılık ve toksik liderliğe ilişkin algilarına ait bulgular Tablo 1'de yer almaktadır. 
Tablo 1. Banka Çalışanlarının Toksik Liderlik ve İş Tatmini Algıları

\begin{tabular}{llll}
\hline & $\overline{\mathrm{X}}$ & ss. & Düzey \\
\hline Değer Bilmezlik & 2,27 & 1,036 & Katılmıyorum \\
\hline Çıkarclık & 2,32 & 1,066 & Katılmıyorum \\
\hline Bencillik & 2,52 & 1,034 & Katılmıyorum \\
\hline Olumsuz Ruhsal Durum & 2,66 & 1,243 & O.Düzeyde Katıllıorum \\
\hline Toksik Liderlik Genel & 2,39 & 1,006 & Katılmıyorum \\
\hline Duygusal Bağlılık & 3,57 & 0,759 & Katıllyorum \\
\hline Devam Bağllık & 3,37 & 0,593 & O.Düzeyde Katıllıorum \\
\hline Normatif Bağllık & 3,45 & 0,749 & Katıllyorum \\
\hline Örgütsel Bağlılık Genel & 3,46 & 0,544 & Katıllyorum \\
\hline
\end{tabular}

Araştırmaya katılan banka çalışanlarının toksik liderlik ölçeğine verdikleri cevapların ortalama ve standart sapmaları incelendiğinde katılımcıların ölçeğin "Değer Bilmezlik" boyutunda "Katılmıyorum (Ort.= 2,27)"; "Çıkarcllık" boyutunda "Katılmıyorum (Ort.= 2,32)"; "Bencillik" boyutunda "Katilmiyorum (Ort.= 2,52)"; "Olumsuz Ruhsal Durum" boyutunda "Orta Düzeyde Katılıyorum (Ort.= 2,66)" ve "Toksik Liderlik Genel" boyutunda "Katılmiyorum (Ort.= 2,39)" düzeyinde cevap verdikleri belirlenmiştir.

Araştırmaya katılan banka çalışanlarının örgütsel bağlılık ölçeğine verdikleri cevapların ortalama ve standart sapmaları incelendiğinde katılımcıların ölçeğin "Duygusal Bağlılık" boyutunda "Katılıyorum (Ort.= 3,57)"; "Devam Bağlılığı" boyutunda "Orta Düzeyde Katılıyorum (Ort.= 3,37)"; "Normatif Bağlllık" boyutunda "Katıllyorum (Ort.= 3,45)" ve “Örgütsel Bağlllık Genel” boyutunda "Katılıyorum (Ort.= 3,46)" düzeyinde cevap verdikleri belirlenmiştir.

\section{Toksik Liderlik Bulgular}

Bankada görev yapan çalışanların toksik liderliğe ilişkin algıları cinsiyet, medeni durum, eğitim durumu, mesleki tecrübe, bulunduğu kurumda çalışma süresi ve kurumda görev alınan pozisyon değişkenlerine göre anlamlı farklılık gösterip göstermediğine ilişkin bulgular aşağıda Tablo 2-34 'te yer almaktadir. 
Tablo 2. Cinsiyet Değişkenine Göre Toksik Liderlik Algılan

\begin{tabular}{|c|c|c|c|c|c|c|}
\hline Boyutlar & Cinsiyet & $\mathbf{N}$ & $\overline{\mathrm{X}}$ & ss. & $t$ & $\mathbf{P}$ \\
\hline \multirow[t]{2}{*}{ Değer Bilmezlik } & Erkek & 174 & 2,34 & 1,124 & \multirow[t]{2}{*}{1,397} & \multirow[t]{2}{*}{,14 } \\
\hline & Kadın & 128 & 2,17 & 0,898 & & \\
\hline \multirow[t]{2}{*}{ Çıkarcılık } & Erkek & 174 & 2,41 & 1,137 & \multirow[t]{2}{*}{1,761} & \multirow[t]{2}{*}{07} \\
\hline & Kadın & 128 & 2,20 & 0,952 & & \\
\hline \multirow[t]{2}{*}{ Bencillik } & Erkek & 174 & 2,57 & 1,072 & \multirow[t]{2}{*}{0,877} & \multirow[t]{2}{*}{,38 } \\
\hline & Kadın & 128 & 2,46 & 0,981 & & \\
\hline \multirow[t]{2}{*}{ Olumsuz Ruhsal Durum } & Erkek & 174 & 2,73 & 1,256 & \multirow[t]{2}{*}{1,087} & \multirow[t]{2}{*}{,27 } \\
\hline & Kadın & 128 & 2,57 & 1,223 & & \\
\hline \multirow[t]{2}{*}{ GENEL } & Erkek & 174 & 2,46 & 1,068 & \multirow[t]{2}{*}{1,462} & \multirow[t]{2}{*}{ 10 } \\
\hline & Kadın & 128 & 2,29 & 0,909 & & \\
\hline
\end{tabular}

Yukanda yer alan bağımsız örneklemler t-Testi verileri incelendiğinde, banka çalışanlarının toksik liderliğe ilişkin algıları arasında "cinsiyet" değişkenine göre anlamlı farklılık olmadığı tespit edilmiştir ( $p>, 05)$. Cinsiyet değişkenine göre banka çalışanlarının algıları arasında anlamlı farklılığın tespit edilmediği toksik liderlik ölçeğinde erkek ve kadınların ortalamaları incelendiğinde en yüksek ortalamanın "Olumsuz Ruhsal Durum" boyutunda olduğu saptanmıştır (Ort.erkek= 2,73 > Ort.kadı $=2,57)$.

Tablo 3. Medeni Durum Değişkenine Göre Toksik Liderlik Algıları

\begin{tabular}{|c|c|c|c|c|c|c|}
\hline Boyutlar & Medeni Durum & $\mathbf{N}$ & $\overline{\mathrm{X}}$ & ss. & $t$ & $\mathbf{P}$ \\
\hline \multirow[t]{2}{*}{ Değer Bilmezlik } & Evli & 201 & 2,20 & 0,980 & \multirow[t]{2}{*}{$-1,696$} & \multirow[t]{2}{*}{,09 } \\
\hline & Bekâr & 101 & 2,41 & 1,132 & & \\
\hline \multirow[t]{2}{*}{ Çıkarcılık } & Evli & 201 & 2,24 & 1,014 & \multirow[t]{2}{*}{$-1,803$} & \multirow[t]{2}{*}{,08 } \\
\hline & Bekâr & 101 & 2,48 & 1,154 & & \\
\hline \multirow[t]{2}{*}{ Bencillik } & Evli & 201 & 2,43 & 0,962 & \multirow[t]{2}{*}{$-2,187$} & \multirow[t]{2}{*}{,03 } \\
\hline & Bekâr & 101 & 2,70 & 1,148 & & \\
\hline \multirow[t]{2}{*}{ Olumsuz Ruhsal Durum } & Evli & 201 & 2,61 & 1,205 & \multirow[t]{2}{*}{$-1,058$} & \multirow[t]{2}{*}{,29 } \\
\hline & Bekâr & 101 & 2,77 & 1,314 & & \\
\hline \multirow[t]{2}{*}{ GENEL } & Evli & 201 & 2,32 & 0,952 & \multirow[t]{2}{*}{$-1,807$} & \multirow[t]{2}{*}{07} \\
\hline & Bekâr & 101 & 2,54 & 1,095 & & \\
\hline
\end{tabular}

Bağımsız örneklemler t-Testi verileri medeni durum değişkeni açısından incelendiğinde, banka çalışanlarının toksik liderliğe ilişkin algıları arasında "medeni durum" değişkeni açısından anlamlı farklılığın "Bencillik" boyutunda olduğu belirlenmiştir ( $\mathrm{t}=-2,187 ; \mathrm{p}=, 03)$. Medeni durum değişkenine göre banka çalışanlarının algıları arasında anlamlı farklılığın tespit edildiği "Bencillik" boyutunda bulunan anlamlı farklılığın bekâr olan 
banka çalışanları lehine olduğu görülmektedir $($ Ort.bekâr $=2,70>$ Ort.evli $=$ 2,43). Ayrıca elde edilen bu verilerden "Bencillik" boyutunda araştırmaya katılan banka çalışanlarının algılarının birbirine benzemediği söylenebilir.

Banka çalışanlarının toksik liderliğe ilişkin algıları arasında "medeni durum" değiş̧keni açısından anlamlı farklılık, "Değer Bilmezlik", "Çıkarcılık", "Olumsuz Ruhsal Durum", "Toksik Liderlik Genel" boyutlarında belirlenmemiştir ( $p>$,05). Başka bir ifade ile "Değer Bilmezlik", "Çıkarclık", "Olumsuz Ruhsal Durum", "Toksik Liderlik Genel" boyutlarında banka çalışanlarının görüşlerinin birbirine benzer olduğu söylenebilir.

Tablo 4. Toksik Liderliğe İlişkin Tek Yönlü Varyans Analizleri

\begin{tabular}{|c|c|c|c|c|c|c|}
\hline & Özellikler & $\begin{array}{l}\text { Değer } \\
\text { Bilmezlik }\end{array}$ & Çıkarcılık & Bencillik & $\begin{array}{l}\text { Olumsuz } \\
\text { Ruhsal } \\
\text { Durum } \\
\end{array}$ & $\begin{array}{l}\text { Toksik } \\
\text { Liderlik } \\
\text { Genel } \\
\end{array}$ \\
\hline & & Ort. \pm ss. & Ort. \pm ss. & Ort. \pm ss. & Ort. \pm ss. & Ort. \pm ss. \\
\hline \multirow{5}{*}{ 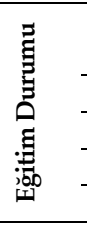 } & $\begin{array}{l}\text { lise ve } \\
\text { ön lisans }\end{array}$ & $2,13 \pm 0,927$ & $2,02+0,939$ & $2,36 \pm 1,183$ & $2,50 \pm 1,367$ & $2,20 \pm 1,003$ \\
\hline & lisans & $2,26 \pm 1,014$ & $2,33 \pm 1,046$ & $2,53 \pm 1,016$ & $2,66 \pm 1,214$ & $2,39 \pm 0,982$ \\
\hline & lisansüstü & $2,45 \pm 1,267$ & $2,46 \pm 1,285$ & $2,57 \pm 1,087$ & $2,80 \pm 1,390$ & $2,53 \pm 1,190$ \\
\hline & $\mathrm{F}$ & 0,720 & 1,162 & 0,322 & 0,380 & 0,730 \\
\hline & $p$ & 48 & ,31 & 72 & 68 & 48 \\
\hline \multirow{5}{*}{ 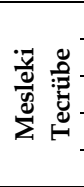 } & 5 yil ve altı & $2,25 \pm 1,022$ & $2,37 \pm 1,077$ & $2,51 \pm 1,010$ & $2,60 \pm 1,210$ & $2,39 \pm 0,992$ \\
\hline & 6-10 yil & $2,36 \pm 1,112$ & $2,37 \pm 1,109$ & $2,61 \pm 1,120$ & $2,83 \pm 1,318$ & $2,48 \pm 1,069$ \\
\hline & 10 yıl üzeri & $2,16 \pm 0,932$ & $2,17 \pm 0,981$ & $2,41 \pm 0,928$ & $2,50 \pm 1,154$ & $2,26 \pm 0,921$ \\
\hline & $\mathrm{F}$ & 0,934 & 0,954 & 0,889 & 1,763 & 1,100 \\
\hline & $\mathrm{p}$ & ,39 & 38 & 41 & 17 & 33 \\
\hline \multirow{5}{*}{ 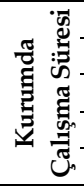 } & 5 yil ve altı & $2,30 \pm 1,086$ & $2,38 \pm 1,070$ & $2,52 \pm 1,015$ & $2,69 \pm 1,279$ & $2,43 \pm 1,010$ \\
\hline & 6-10 yıl & $2,34 \pm 1,062$ & $2,38 \pm 1,106$ & $2,65 \pm 1,078$ & $2,77 \pm 1,246$ & $2,47 \pm 1,043$ \\
\hline & 10 yıl üzeri & $2,09 \pm 0,877$ & $2,10 \pm 0,972$ & $2,31 \pm 0,971$ & $2,42+1,148$ & $2,19 \pm 0,914$ \\
\hline & $\mathrm{F}$ & 1,315 & 1,759 & 2,152 & 1,667 & 1,835 \\
\hline & $\mathrm{p}$ &, 27 &, 17 &, 11 & 19 &, 16 \\
\hline \multirow{8}{*}{ 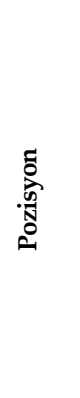 } & memur & $2,20 \pm 1,041$ & $2,30 \pm 1,074$ & $2,48 \pm 1,085$ & $2,60 \pm 1,268$ & $2,34 \pm 1,005$ \\
\hline & $\begin{array}{l}\text { Yetkili Yrd- } \\
\text { Yetkili }\end{array}$ & $2,31 \pm 0,945$ & $2,41 \pm 1,026$ & $2,60 \pm 1,009$ & $2,73 \pm 1,202$ & $2,46 \pm 0,959$ \\
\hline & Üst Yetkili & $1,79 \pm 0,816$ & $1,64 \pm 0,683$ & $1,99 \pm 1,039$ & $2,04 \pm 1,140$ & $1,82 \pm 0,812$ \\
\hline & $\begin{array}{l}\text { Uzman } \\
\text { Yrd-Uzman }\end{array}$ & $2,66 \pm 1,326$ & $2,60 \pm 1,155$ & $2,64 \pm 0,885$ & $3,03 \pm 1,255$ & $2,70 \pm 1,120$ \\
\hline & Mdr. Yrd. & $2,33 \pm 1,333$ & $2,16 \pm 1,341$ & $2,58 \pm 1,037$ & $2,62+1,376$ & $2,37 \pm 1,239$ \\
\hline & $\mathrm{F}$ & 2,190 & 2,864 & 1,721 & 2,007 & 2,477 \\
\hline & $\mathrm{p}$ & ,07 & ,02 & 14 & ,09 & ,04 \\
\hline & $\begin{array}{l}\text { Anlamlı } \\
\text { Fark }\end{array}$ & & $1>3,2>3,4>3$ & & & $1>3,2>3,4>3$ \\
\hline
\end{tabular}


Yukarıda yer alan Tek Yönlü Varyans Analizi (ANOVA) verileri incelendiğinde, banka çalışanlarının toksik liderliğe ilişkin algıları arasında "kurumda görev alınan pozisyon" değişkenine göre "Çıkarcılık" ve "Toksik Liderlik Genel" boyutlarında anlamlı farklılık olduğu tespit edilmiştir $\left(F_{\text {çikarcllik }}=2,864 ; p_{\text {çikarcllk }}=0,02 ; F_{\text {toksik liderlik genel }}=2,477 ;\right.$ ptoksik liderlik genel $\left.=, 04\right)$. Bulunan anlamlı farklılığın hangi pozisyonda görev alan banka çalışanları arasında olduğunu tespiti için Scheffe testi yapılmıştır. Scheffe testi neticesinde anlamlı farklılığın kurumda pozisyonu "memur ile üst yetkili"; "yetkili yardımcı-yetkili ile üst yetkili"; "uzman yardımcısı-uzman ile üst yetkili" olanlar arasında olduğu saptanmıştır.

Yukarıda yer alan ANOVA verileri incelendiğinde, banka çalışanlarının kurumda görev alınan pozisyon değişkenine göre "Değer Bilmezlik", "Bencillik", "Olumsuz Ruhsal Durum" boyutlarında algilarının anlamlı farklılık göstermediği belirlenmiştir $(p>, 05)$. Başka bir ifade ile banka çalışanlarının "Değer Bilmezlik", "Bencillik", "Olumsuz Ruhsal Durum" boyutlarındaki algılarının eğitim durumu, mesleki tecrübe, kurumda çalışma süresi ve pozisyon değişkenlerinde birbirine yakın olduğu söylenebilir.

Yukarıda yer alan ANOVA verileri incelendiğinde, banka çalışanlarının toksik liderlik algıları eğitim durumu, mesleki tecrübe ve kurumda çalışma süresi değişkenlerine göre anlamlı farklılık taşımadığı belirlenmiştir.

\section{Örgütsel Bağhlılk Bulgularn}

Bankada görev yapan çalışanların örgütsel bağlllığa ilişkin görüşleri arasında cinsiyet, medeni durum, eğitim durumu, mesleki tecrübe, bulunduğu kurumda çalışma süresi ve kurumda görev alınan pozisyon değişkenlerine göre anlamlı farklılık gösterip göstermediğine ilişkin bulgular aşağıda Tablo 5-6-7'de yer almaktadır. 
Tablo 5. Banka Çalışanlarının Cinsiyet Değişkenine Göre Örgütsel Bă̆lılık Algıları

\begin{tabular}{|c|c|c|c|c|c|c|}
\hline Boyutlar & Cinsiyet & $\mathbf{N}$ & $\overline{\mathrm{X}}$ & ss. & $t$ & $\mathbf{p}$ \\
\hline \multirow[t]{2}{*}{ Duygusal Bağlılık } & Erkek & 174 & 3,51 & 0,793 & \multirow[t]{2}{*}{$-1,521$} & \multirow[t]{2}{*}{0,12} \\
\hline & Kadın & 128 & 3,65 & 0,707 & & \\
\hline \multirow[t]{2}{*}{ Devam Bağlılık } & Erkek & 174 & 3,31 & 0,628 & \multirow[t]{2}{*}{$-2,082$} & \multirow[t]{2}{*}{0,03} \\
\hline & Kadın & 128 & 3,46 & 0,533 & & \\
\hline \multirow[t]{2}{*}{ Normatif Bağlılık } & Erkek & 174 & 3,46 & 0,759 & \multirow[t]{2}{*}{0,210} & \multirow[t]{2}{*}{0,83} \\
\hline & Kadın & 128 & 3,44 & 0,737 & & \\
\hline \multirow[t]{2}{*}{ GENEL } & Erkek & 174 & 3,43 & 0,565 & \multirow[t]{2}{*}{$-1,363$} & \multirow[t]{2}{*}{0,17} \\
\hline & Kadın & 128 & 3,51 & 0,513 & & \\
\hline
\end{tabular}

Tablo 5'teki bağımsız örneklemler t-Testi verileri cinsiyet değişkeni açısından incelendiğinde, banka çalışanlarının örgütsel bağlllığa ilişkin algıları arasında "cinsiyet" değişkeni açısından anlamlı farklılı̆̆ın yalnızca "Devam Bağlllığı" boyutunda olduğu tespit edilmiştir $(\mathrm{t}=-2,082 ; \mathrm{p}=, 03)$. Cinsiyet değişkenine göre banka çalışanlarının algıları arasında anlamlı farklılığın tespit edildiği "Devam Bağlılığı” boyutunda anlamlı farklılığın kadınların lehine olduğu görülmüştür (Ort.kadı $=3,46>$ Ort.erkek $=3,31$ ). Ayrıca elde edilen bu verilerden "Devam Bağl1lı̆̆ı" boyutunda araştırmaya katılan banka çalışanlarının algılarının birbirine benzemediği söylenebilir.

Banka çalışanlarının örgütsel bağlılığa ilişkin algıları arasında "cinsiyet" değişkenine açısından "Duygusal Bağlılık, Normatif Bağlllık, Örgütsel Bağlılık Genel" boyutlarında anlamlı farklılık olmadığı belirlenmiştir (p > ,05). Başka bir ifade ile “Duygusal Bağlılık, Normatif Bağlllık, Örgütsel Bağlılık Genel” boyutlarında banka çalışanlarının görüşlerinin birbirine benzer olduğu söylenebilir.

Tablo 6. Banka Çalışanlarnın Medeni Durum Değişkenine Göre Örgütsel Bă̆hlık

\begin{tabular}{lllllll} 
Algılarn & & & & & & \\
\hline Boyutlar & Medeni Durum & $\mathbf{N}$ & $\overline{\mathbf{X}}$ & ss. & $\mathbf{t}$ & $\mathbf{p}$ \\
\hline Duygusal Bağılık & Evli & 201 & 3,62 & 0,745 & 1,760 & 0,07 \\
& Bekâr & 101 & 3,46 & 0,779 & & \\
\hline Devam Bağlılık & Evli & 201 & 3,38 & 0,593 & 0,049 & 0,96 \\
& Bekâr & 101 & 3,37 & 0,596 & & \\
\hline Normatif Bağılık & Evli & 201 & 3,42 & 0,744 & $-0,953$ & 0,34 \\
& Bekâr & 101 & 3,51 & 0,759 & & \\
\hline GENEL & Evli & 201 & 3,47 & 0,539 & 0,396 & 0,69 \\
& Bekâr & 101 & 3,45 & 0,556 & & \\
\hline
\end{tabular}


Tablo 6'daki bağımsız örneklemler t-Testi verileri incelendiğinde, banka çalışanlarının örgütsel bağlılığa ilişkin algıları arasında "medeni durum" değişkenine göre anlamlı farklılık olmadı̆̆ 1 tespit edilmiştir $(p>, 05)$. Medeni durum değişkenine göre banka çalışanlarının algıları arasında anlamlı farklılığın tespit edilmediği örgütsel bağlılık ölçeğinde evli olanların ortalamaları incelendiğinde "Duygusal Bağlılık", bekâr olanların ise "Normatif Bağlllık" boyutunda en yüksek ortalamaların olduğu saptanmıştır (Ort.evli = 3,62; Ort. bekâr $=3,51$ ).

Tablo 7'deki "Tek Yönlü Varyans Analizi” verileri incelendiğinde, banka çalışanlarının örgütsel bağlıllğa ilişkin algıları arasında "eğitim durumu" değişkenine göre "Normatif Bağlllık ve Örgütsel Bağlllık Genel" boyutlarında anlamlı farklılık olduğu tespit edilmiştir (Fnormatif bağ. $=5,665$; pnormatif bağ. $=, 00 ; \mathrm{Fö.bağ.} \mathrm{genel}=3,031$; pö.bağ. genel $=, 04$ ). Bulunan anlamlı farklılığın hangi gruplar arasında olduğunu tespiti için "Scheffe testi" yapılmıştır. "Scheffe testi" neticesinde anlamlı farklılığın lise-önlisans mezunları ile lisans mezunları arasında, lise-önlisans mezunları ile lisansüstü mezunları arasında olduğu saptanmıştır.

Tablo 7. Örgütsel Bağhllı̆̆a İlişkin Tek Yönlü Varyans Analizleri

\begin{tabular}{|c|c|c|c|c|}
\hline $\begin{array}{l}\text { Demografik } \\
\text { Özellikler }\end{array}$ & $\begin{array}{l}\text { Duygusal } \\
\text { Bağllilı }\end{array}$ & $\begin{array}{l}\text { Devam } \\
\text { Bağlılığı }\end{array}$ & Normatif Bağlılık & $\begin{array}{l}\text { Örgütsel Bağlılık } \\
\text { Genel }\end{array}$ \\
\hline Eğitim Durumu & Ort. \pm ss. & Ort. \pm ss. & Ort. \pm ss. & Ort. \pm ss. \\
\hline 1. lise ve ön lisans & $3,77 \pm 0,633$ & $3,46 \pm 0,829$ & $3,94 \pm 0,734$ & $3,73 \pm 0,550$ \\
\hline 2. lisans & $3,56 \pm 0,765$ & $3,38 \pm 0,570$ & $3,41 \pm 0,690$ & $3,45 \pm 0,527$ \\
\hline 3. lisans üstü & $3,53 \pm 0,794$ & $3,27 \pm 0,574$ & $3,40 \pm 1,039$ & $3,40 \pm 0,630$ \\
\hline$F=$ & 0,890 & 0,778 & 5,665 & 3,031 \\
\hline $\mathrm{p}=$ & 0,41 & 0,46 & 0,00 & 0,04 \\
\hline Anlamlı Fark & & & $1>2,1>3$ & $1>2,1>3$ \\
\hline \multicolumn{5}{|l|}{ Mesleki Tecrübe } \\
\hline 1.5 yil ve alt & $3,48 \pm 0,754$ & $3,40 \pm 0,569$ & $3,46 \pm 0,770$ & $3,44 \pm 0,541$ \\
\hline 2. $6-10 \mathrm{yll}$ & $3,49 \pm 0,772$ & $3,37 \pm 0,590$ & $3,33 \pm 0,746$ & $3,39 \pm 0,547$ \\
\hline 3.10 yil üzeri & $3,84 \pm 0,689$ & $3,35 \pm 0,637$ & $3,61 \pm 0,695$ & $3,60 \pm 0,527$ \\
\hline $\mathrm{F}=$ & 6,521 & 0,151 & 3,428 & 3,494 \\
\hline $\mathrm{p}=$ & 0,00 & 0,86 & 0,03 & 0,03 \\
\hline Anlamlı Fark & $3>1,3>2$ & & $3>2$ & $3>2$ \\
\hline \multicolumn{5}{|c|}{ Kurumda Çalışma Süresi } \\
\hline 1.5 yil ve alt & $3,42 \pm 0,833$ & $3,36 \pm 0,614$ & $3,41 \pm 0,831$ & $3,40 \pm 0,609$ \\
\hline 2. 6-10 yll & $3,58 \pm 0,657$ & $3,39 \pm 0,541$ & $3,36 \pm 0,652$ & $3,44 \pm 0,450$ \\
\hline 3. 10 yil üzeri & $3,84 \pm 0,709$ & $3,37 \pm 0,644$ & $3,67 \pm 0,707$ & $3,63 \pm 0,539$ \\
\hline $\mathrm{F}=$ & 6,760 & 0,106 & 3,863 & 3,992 \\
\hline $\mathrm{p}=$ & 0,00 & 0,89 & 0,02 & 0,01 \\
\hline Anlamlı Fark & $3>1,3>2$ & & $3>1,3>2$ & $3>1,3>2$ \\
\hline
\end{tabular}




\begin{tabular}{lllll}
\hline Pozisyon & \multicolumn{5}{l}{} \\
\hline 1. memur & $3,54 \pm 0,846$ & $3,43 \pm 0,662$ & $3,52 \pm 0,809$ & $3,49 \pm 0,630$ \\
2.yetkili yrd-yetkili & $3,54 \pm 0,659$ & $3,42 \pm 0,492$ & $3,42 \pm 0,668$ & $3,46 \pm 0,446$ \\
3. üst yetkili & $3,80 \pm 0,522$ & $3,38 \pm 0,769$ & $3,60 \pm 0,891$ & $3,59 \pm 0,579$ \\
4. uzman yrd-uzman & $3,29 \pm 0,926$ & $3,02 \pm 0,496$ & $3,17 \pm 0,838$ & $3,16 \pm 0,586$ \\
5. mdr. yrd. & $4,19 \pm 0,648$ & $3,21 \pm 0,682$ & $3,53 \pm 0,645$ & $3,64 \pm 0,511$ \\
F= & 4,314 & 3,049 & 1,374 & 2,843 \\
p= & $\mathbf{0 , 0 0}$ & $\mathbf{0 , 0 1}$ & 0,24 & $\mathbf{0 , 0 2}$ \\
Anlamlı Fark & $5>1,5>2$, & $1>4,2>4,3>4$ & & $1>4,2>4,3>4,5>4$ \\
& $3>4,5>4$ & & & \\
\hline
\end{tabular}

Tablo 7'deki Tek Yönlü Varyans Analizi verileri incelendiğinde, banka çalışanlarının örgütsel bağlılığa ilişkin algıları arasında "mesleki tecrübe" değişkenine göre "Duygusal Bağlılık, Normatif Bağlllık ve Örgütsel Bağlllık Genel" boyutlarında anlamlı farklılık olduğu tespit edilmiştir (Fduygusal bağ. $=$

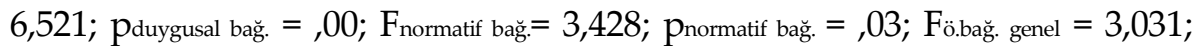
pöbağhllik genel $=, 03)$. Bulunan anlamlı farklılığın hangi gruplar arasında olduğunu tespiti için "Scheffe testi" yapılmıştır. "Scheffe testi" neticesinde anlamlı farklılığın her üç boyutta 10 yıl üzeri mesleki tecrübeye sahip olan banka çalışanları ile 6-10 yıl arası mesleki tecrübeye sahip olan banka çalışanları arasında olduğu saptanmıştır. Ayrıca Duygusal Bağlılık boyutunda anlamlı farklılığı 10 yıl üzeri mesleki tecrübeye sahip olan banka çalışanlanı ile 5 yıl ve altında mesleki tecrübeye sahip olan banka çalışanları arasında olduğu belirlenmiştir.

Tablo 7'deki Tek Yönlü Varyans Analizi verileri incelendiğinde, banka çalışanlarının örgütsel bağlılığa ilişkin algıları arasında "kurumda çalışma süresi” değişkenine göre "Duygusal Bağlllık, Normatif Bağlllık ve Örgütsel Bağlılık Genel" boyutlarında anlamlı farklılık olduğu tespit edilmiştir

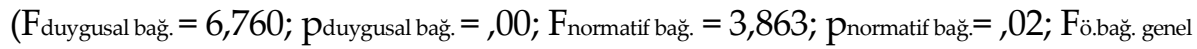
$=3,992 ;$ pö.bağ. genel = ,01). Bulunan anlamlı farklılığın hangi gruplar arasında olduğunu tespiti için "Scheffe testi" yapılmıştır. "Scheffe testi" neticesinde anlamlı farklılığın her üç boyutta 10 yıl üzeri kurumda çalışanlar ile 6-10 yıl ile 5 yıl ve altında aynı kurumda görev yapan banka çalışanları arasında olduğu belirlenmiştir.

Tablo 7'deki Tek Yönlü Varyans Analizi verileri incelendiğinde, banka çalışanlarının örgütsel bağlılığa ilişkin algıları arasında "kurumdaki pozisyon" değişkenine göre "Duygusal Bağlllık, Devam Bağlılı̆̆1 ve Örgütsel Bağllık Genel" boyutlarında anlamlı farklılık olduğu tespit 


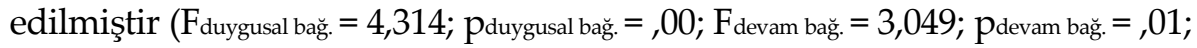
Fö.bă̆. genel= 2,843; pö.bağ. genel= ,02). Bulunan anlamlı farklılı̆̆ın hangi gruplar arasında olduğunu tespiti için "Scheffe testi" yapılmıştır. "Scheffe testi" neticesinde anlamlı farklılı̆̆ın;

Duygusal Bağll1ık boyutunda, Müdür Yardımcisı>Memur, Müdür Yardımcısı> Yetkili yardımcı-yetkili, Üst Yetkili > Uzman YardımcısıUzman, Müdür Yardımcisı > Uzman Yardımcisı-Uzman pozisyonunda görev yapan banka çalışanları arasında;

Devam Bağlllığı boyutunda, Memur> Uzman Yardımcısı-Uzman, Yetkili yardımcı-yetkili > Uzman Yardımcısı-Uzman, Üst Yetkili > Uzman Yardımcısı-Uzman pozisyonunda görev yapan banka çalışanları arasında;

Örgütsel Bağlllık Genel boyutunda, Memur > Uzman YardımcısıUzman, Yetkili yardımcı-yetkili > Uzman Yardımcısı-Uzman, Üst Yetkili > Uzman Yardımcısı-Uzman, Müdür Yardımcısı > Uzman Yardımcısı-Uzman pozisyonunda görev yapan banka çalışanları arasında olduğu saptanmıştır.

Tablo 7'deki Tek Yönlü Varyans Analizi verileri incelendiğinde, "eğitim durumu" değişkeninde duygusal ve devam bağllı̆̆g boyutlarında; "mesleki tecrübe ve kurumda çalışma süresi" değişkenlerinde devam bağlllığ boyutunda; "kurumdaki pozisyon" değişkeninde normatif bağlllık boyutlarında banka çalışanlarının algıları arasında anlamlı farklılık olmadığ 1 belirlenmiştir ( $p>$,05). Başka bir ifade ile banka çalışanlarının sayılan değişken ve boyutlarda algılarının birbirine benzer olduğu söylenebilir.

\section{Örgütsel Bağhlık ve Toksik Liderlik Arasındaki İlişkiye Ait Bulgular}

Bankada görev yapan çalışanların örgütsel bağlılık ve toksik liderlik algıları arasında ilişkinin tespiti için yapılan korelasyon analizi bulguları aşağıda Tablo 8'de yer almaktadır. 
Tablo 8. Örgütsel Bağhllk ve Toksik Liderliğe İlişkin Korelasyon Analizi

\begin{tabular}{|c|c|c|c|c|c|c|}
\hline & & 莺 & 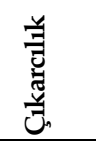 & 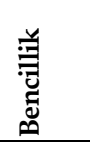 & 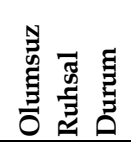 & تِّ \\
\hline \multirow{2}{*}{ Duygusal Bağlılık } & $\mathrm{r}$ &,$- 317^{* *}$ &,$- 304^{* *}$ &,$- 193^{* *}$ &,$- 241^{* *}$ &,$- 299 * *$ \\
\hline & $\mathrm{p}$ &, 00 & , 00 & ,00 & , 00 & ,00 \\
\hline \multirow{2}{*}{ Devam Bağlılığı } & $\mathrm{r}$ &,$- 249^{* *}$ & $-198^{* *}$ &,$- 182^{* *}$ &,$- 165^{* *}$ &,$- 222^{* *}$ \\
\hline & $\bar{p}$ & ,00 & , 00 & ,00 & , 00 & , 00 \\
\hline \multirow{2}{*}{ Normatif Bağlılık } & $\mathrm{r}$ &,$- 208^{* *}$ & $-168^{* *}$ &,$- 132^{*}$ &,- 105 & $-176^{* *}$ \\
\hline & $\mathrm{p}$ &, 00 &, 00 & , 02 & 0,07 & , 00 \\
\hline \multirow{2}{*}{ Örgütsel Bağlılık Genel } & $\mathrm{r}$ &,$- 333^{* *}$ &,$- 290^{* *}$ &,$- 216^{* *}$ &,$- 220^{* *}$ &,$- 301^{* *}$ \\
\hline & $\mathrm{p}$ & ,00 & , 00 & ,00 & ,00 & ,00 \\
\hline
\end{tabular}

$*<0,05 ;{ }^{* *}<0,01$

Tablo 8'de toksik liderlik ve örgütsel bağlılık arasındaki korelasyona ilişkin veriler incelendiğinde Duygusal Bağlılık boyutunda şu bulgulara ulaşılmıştır:

- "Duygusal Bağlılık" ve "Değer Bilmezlik" boyutları arasında negatif yönlü orta düzeyde,

- "Duygusal Bağlılık" ve "Çıkarcılık" boyutları arasında negatif yönlü orta düzeyde,

- "Duygusal Bağlılık" ve "Bencillik" boyutları arasında negatif yönlü düşük düzeyde,

- "Duygusal Bağlılık" ve "Olumsuz Ruhsal Durum" boyutları arasında negatif yönlü düşük düzeyde,

- "Duygusal Bağlılık" ve "Toksik Liderlik Genel” boyutları arasında negatif yönlü düşük düzeyde bulunmaktadır.

Tablo 8'de Devam Bağlılı̆̆g boyutunda şu bulgulara ulaşılmıştır:

- "Devam Bağlılık" ve "Değer Bilmezlik" boyutları arasında negatif yönlü düşük düzeyde,

- "Devam Bağlılık" ve "Çıkarcılık" boyutları arasında negatif yönlü düşük düzeyde,

- "Devam Bağlılık" ve "Bencillik" boyutları arasında negatif yönlü düşük düzeyde, 
- "Devam Bağl1lık" ve "Olumsuz Ruhsal Durum" boyutları arasında negatif yönlü düşük düzeyde,

- "Devam Bağlılık" ve "Toksik Liderlik Genel" boyutları arasında negatif yönlü düşük düzeyde bulunmaktadır.

Tablo 8'de Normatif Bağlılık boyutunda şu bulgulara ulaşılmıştır:

- "Normatif Bağlllık" ve "Değer Bilmezlik" boyutları arasında negatif yönlü düşük düzeyde,

- "Normatif Bağlılık" ve "Çıkarcılık" boyutları arasında negatif yönlü düşük düzeyde,

- "Normatif Bağlllık" ve "Bencillik" boyutları arasında negatif yönlü düşük düzeyde,

- "Normatif Bağlllık" ve "Toksik Liderlik Genel" boyutları arasında negatif yönlü düşük düzeyde bulunmaktadır

Tablo 8'de Örgütsel Bağl1lık Genel boyutunda şu bulgulara ulaşılmıştır:

- "Örgütsel Bağlılık Genel" ve "Değer Bilmezlik" boyutları arasında negatif yönlü orta düzeyde,

- "Örgütsel Bağlılık Genel" ve "Çıkarcılık" boyutları arasında negatif yönlü düşük düzeyde,

- "Örgütsel Bağlılık Genel" ve "Bencillik" boyutları arasında negatif yönlü düşük düzeyde,

- “Örgütsel Bağlılık Genel” ve "Olumsuz Ruhsal Durum" boyutları arasında negatif yönlü düşük düzeyde,

- "Örgütsel Bağlılık Genel" ve “Toksik Liderlik Genel” boyutları arasında negatif yönlü düşük düzeyde bulunmaktadır.

\section{Toksik Liderliğin İş Tatminini Etkileme Düzeyine İlişkin Bulgular}

Bankada görev yapan çalışanların örgütsel bağl1lı̆̆ına yöneticilerinin göstermiş olduğu toksik liderlik davranışlarının etki edip etmediğine ilişkin basit doğrusal regresyon analizi bulguları aşağıda Tablo 9'da yer almaktadır. 
Tablo 9. Toksik Liderlik Alt Boyutlarının İçsel Tatmin Üzerine Etkisi

\begin{tabular}{|c|c|c|c|c|c|c|c|}
\hline $\begin{array}{l}\text { Bağımlı } \\
\text { Değişken }\end{array}$ & Bağımsız Değişken & В & $t$ & $\mathbf{p}$ & $\mathbf{F}$ & Model (p) & $\mathbf{R}^{2}$ \\
\hline \multirow{5}{*}{$\begin{array}{l}\text { Duygusal } \\
\text { Bağllilık }\end{array}$} & Sabit & 4,038 & 36,007 & ,00 & \multirow{5}{*}{$-9,312$} & \multirow{5}{*}{,00 } & \multirow{5}{*}{0,099} \\
\hline & Değer Bilmezlik & $-0,193$ & $-1,998$ & ,04 & & & \\
\hline & Çıkarcılık & $-0,144$ & $-1,448$ & ,14 & & & \\
\hline & Bencillik & 0,113 & 1,597 & 11 & & & \\
\hline & Olumsuz Ruhsal Durum & 0,010 & 0,164 & 87 & & & \\
\hline \multirow{5}{*}{$\begin{array}{l}\text { Devam } \\
\text { Bağlılık }\end{array}$} & Sabit & 3,692 & 41,184 & 00 & \multirow{5}{*}{5,473} & \multirow{5}{*}{,00 } & \multirow{5}{*}{0,056} \\
\hline & Değer Bilmezlik & $-0,230$ & $-2,981$ &, 00 & & & \\
\hline & Çıkarcılık & 0,075 & 0,938 &, 34 & & & \\
\hline & Bencillik & $-0,033$ & $-0,586$ & ,55 & & & \\
\hline & Olumsuz Ruhsal Durum & 0,045 & 0,895 & ,37 & & & \\
\hline \multirow{5}{*}{$\begin{array}{l}\text { Normatif } \\
\text { Bağllık }\end{array}$} & Sabit & 3,748 & 32,858 &, 00 & \multirow{5}{*}{4,310} & \multirow{5}{*}{,00 } & \multirow{5}{*}{0,042} \\
\hline & Değer Bilmezlik & $-0,268$ & $-2,734$ & ,00 & & & \\
\hline & Çıkarcılık & 0,027 & 0,262 & ,79 & & & \\
\hline & Bencillik & $-0,012$ & $-0,165$ & 86 & & & \\
\hline & Olumsuz Ruhsal Durum & 0,106 & 1,671 & 09 & & & \\
\hline \multirow{2}{*}{$\begin{array}{l}\text { Örgütsel } \\
\text { Bağlılık Genel }\end{array}$} & Sabit & 3,858 & 49,838 & 00 & \multirow{2}{*}{$-29,801$} & \multirow{2}{*}{,00 } & \multirow{2}{*}{0,087} \\
\hline & Toksik Liderlik Genel & $-0,163$ & $-5,459$ & 00 & & & \\
\hline
\end{tabular}

"Değer Bilmezlik", “Çıkarcılık", "Bencillik", “Olumsuz Ruhsal Durum” ile "Duygusal Bağlllık" arasındaki neden sonuç ilişkisi anlamlı bulunmuştur $(\mathrm{F}=9$,312; $\mathrm{p}=$,00). “Duygusal Bağl1lı" düzeyinin belirleyicisi olarak "Değer Bilmezlik", "Çıkarcılık", "Bencillik", "Olumsuz Ruhsal Durum" değişkenleri ile ilişkisinin zayıf düzeyde olduğu bulgusuna ulaşılmıştır $\left(R^{2}=\right.$ 0,099). Banka çalışanlarının algıladıkları "Değer Bilmezlik" düzeyi "Duygusal Bağllık" düzeyini azaltmaktadır $(ß=-0,193)$. Banka çalışanlarının algıladıkları "Çıkarcılık" düzeyi "Duygusal Bağlılık" düzeyini etkilememektedir $(\mathrm{p}=$,14). Banka çalışanlarının algıladıkları "Bencillik" düzeyi "Duygusal Bağlllık" düzeyini etkilememektedir $(\mathrm{p}=, 11)$. Banka çalışanlarının algiladıkları "Olumsuz Ruhsal Durum” düzeyi “Duygusal Bağlllık" düzeyini etkilememektedir $(\mathrm{p}=, 87)$.

"Değer bilmezlik", “Çıkarcılık", "Bencillik", "Olumsuz Ruhsal Durum” ile "Devam Bağlılık" arasındaki neden sonuç ilişkisi anlamlı bulunmuştur $(\mathrm{F}=5,473 ; \mathrm{p}=$,00). "Devam Bağlllık" düzeyinin belirleyicisi olarak "Değer Bilmezlik", "Çıkarcılık", "Bencillik", "Olumsuz Ruhsal Durum" değişkenleri ile ilişkisinin zayıf düzeyde olduğu bulgusuna ulaşılmıştır $\left(R^{2}=\right.$ 0,056). Banka çalışanlarının algıladıkları "Değer Bilmezlik" düzeyi “Devam 
Bağlılık" düzeyini azaltmaktadır $(\Theta=-0,230)$. Banka çalışanlarının algıladıkları "Çıkarcılık" düzeyi "Devam Bağlılık" düzeyini etkilememektedir $(\mathrm{p}=$,34). Banka çalışanlarının algıladıkları "Bencillik" düzeyi "Devam Bağlllı" düzeyini etkilememektedir $(p=$,55). Banka çalışanlarının algıladıkları "Olumsuz Ruhsal Durum" düzeyi Devam Bağllilk düzeyini etkilememektedir $(\mathrm{p}=, 37)$.

"Değer bilmezlik", “Çıkarcılık", "Bencillik”, “Olumsuz Ruhsal Durum” ile "Normatif Bağlılık" arasındaki neden sonuç ilişkisi anlamlı bulunmuştur $(\mathrm{F}=4,310 ; \mathrm{p}=$,00). "Normatif Bağlll1k" düzeyinin belirleyicisi olarak "Değer Bilmezlik", "Çıkarcılık", "Bencillik", "Olumsuz Ruhsal Durum" değişkenleri ile ilişkisinin zayıf düzeyde olduğu bulgusuna ulaşılmıştır $\left(R^{2}=\right.$ 0,042). Banka çalışanlarının algıladığı "Değer Bilmezlik" düzeyi "Normatif Bağlılık" düzeyini azaltmaktadır( $(\$=-0,268)$. Banka çalışanlarının algıladığı "Çıkarcılık" düzeyi "Normatif Bağllık" düzeyini etkilememektedir ( $\mathrm{p}=$,79). Banka çalışanlarının algıladığı "Bencillik" düzeyi "Normatif Bağlılık" düzeyini etkilememektedir $(p=$,869). Banka çalışanlarının algiladığ “Olumsuz Ruhsal Durum" düzeyi "Normatif Bağlllık" düzeyini etkilememektedir $(\mathrm{p}=, 09)$.

"Toksik Liderlik Genel" ile "Örgütsel Bağlılık Genel” arasındaki neden sonuç ilişkisi anlamlı bulunmuştur ( $F=29,801 ; p=$,00). "Örgütsel Bağlllık" düzeyinin belirleyicisi olarak "Toksik Liderlik" ile ilişkisinin zayıf düzeyde olduğu bulgusuna ulaşılmıştır ( $\left.R^{2}=0,087\right)$. Banka çalışanlarının algıladıkları “Toksik Liderlik Genel” düzeyi "Örgütsel Bağlılık Genel” düzeyini azaltmaktadır $(ß=-0,163)$.

\section{Sonuç, Tartışma ve Öneriler}

$\mathrm{Bu}$ çalışmanın amacı liderliğin karanlık yüzü olan zarar verici liderlik davranışlarının örgüt çalışanlarının bağlılığının üzerindeki etkisini araştırmaktır. $\mathrm{Bu}$ amaca ulaşabilmek için ampirik yöntem izlenmiş ve Fenomenolojik bakış açısıyla olguların bağlı bulundukları kapsamdan ayrı düşünülemeyeceği varsayılarak, farklı bağlamların yanlı etkisini önlemek amaciyla bir kamu bankası çalışma evreni olarak alınmıştır. Yapılan araştırmanın analiz edilmesi sonucunda toksik liderliğin örgütsel bağlllık üzerinde etkili olduğu görülmüştür. Bunun yanı sıra detaylı korelasyon analizi sonucunda normatif bağlılık dışındaki tüm örgütsel bağlllık 
boyutlarında, toksik liderlik davranışlarının olumsuz yönde katkısı olduğu sonucuna varılmıştır. Diğer bir deyişle hipotezimiz kabul edilmiştir, yani toksik liderlik davranışları örgütsel bağlılığı genel olarak etkileyerek azalmaktadır. Bununla beraber, ilginç bir şekilde banka çalışanlarının görev algisı belki de yapılan işin kişiler için önemli olması sonucunda ayrılmamaya yönelik ya da o kurumu bırakmamaya yönelik davranışlarda değişiklik gözlemlenmemiştir. Bu durumun kamu bankası olmasından mı kaynaklandığı gelecek araştırmalarda araştırılabilir.

Araştırmaya katılan banka çalışanlarının toksik liderliğe ilişkin algıları "Değer Bilmezlik", "Çıkarcılık", "Bencillik" boyutlarında "Katılmıyorum", "Olumsuz Ruhsal Durum" boyutunda ise "Orta Düzeyde Katılıyorum" düzeyindedir. Araştırmada banka çalışanlarının toksik liderliğe ilişkin verdikleri cevapların genel ortalamasının "Katılmıyorum" düzeyinde olduğu belirlenmiştir. Elde edilen bu sonuçlar doğrultusunda banka yöneticilerinin toksik liderlik davranışlarının düşük seviyede olduğu söylenebilir. Araştırmanın bulguları "Toksik Liderlik Ölçeği Genel”, “Değer Bilmezlik" ve "Çıkarcılık" alt boyutlarında Demirel (2015) ve Çetinkaya'nın (2017) bulguları ile örtüşmektedir. Ayrıca araştırmada banka çalışanlarının toksik liderlik algiları "Bencillik" ve "Olumsuz Ruhsal Durum" boyutlarında diğer boyutlara göre yüksek çıkmıştır. Benzer durum Demirel (2015) ve Çetinkaya'nın (2017) çalışmalarında da bulunmaktadır.

Araştırmada çalışanlarının toksik liderliğe ilişkin algıları arasında "cinsiyet" değişkenine göre anlamlı farklılık olmadığı tespit edilmiştir. Yapılan çalışmada cinsiyet değişkenine göre banka çalışanlarının algıları arasında anlamlı farklılığın tespit edilmediği toksik liderlik ölçeğinde, erkek ve kadın çalışanların ortalamaları incelendiğinde en yüksek ortalamanın "Olumsuz Ruhsal Durum" boyutunda olduğu ve erkeklerin ortalamasının kadınlara göre daha yüksek olduğu saptanmıştır. Başka bir ifade ile erkekler kadınlara göre daha fazla olumuz ruhsal durum yaşamaktadırlar.

Çalışanlarının toksik liderliğe ilişkin algıları arasında "medeni durum" değişkeni açısından anlamlı farklılığın yalnızca "Bencillik" boyutunda olduğu tespit edilmiştir. Bencillik boyutunda benzer sonuç Demirel'in (2015) çalışmasında da elde edilmiştir. Anlamlı farklılığın medeni durum değişkenine göre olmadığı diğer boyutlarda elde edilen sonuçlar, Özer ve arkadaşlarının (2017) yaptığı çalışma sonuçları ile örtüşmektedir. 
Medeni durum değişkenine göre banka çalışanlarının algıları arasında anlamlı farklılığın tespit edildiği "Bencillik" boyutunda anlamlı farklılığın bekârların lehine olduğu görülmüştür. Bu veriler ışığında araştırmada bekâr çalışanlar yöneticilerini daha bencil olarak algıladıkları sonucuna ulaşılabilir.

Banka çalışanlarının toksik liderliğe ilişkin algıları arasında "medeni durum" değişkeni açısından anlamlı farklılık "Değer Bilmezlik", "Çıkarcılık", "Olumsuz Ruhsal Durum", "Toksik Liderlik Genel" boyutlarında tespit edilmemiştir. Başka bir ifade ile sayılan boyutlarda banka çalışanlarının görüşlerinin birbirine benzer olduğu söylenebilir.

Araştırmada banka çalışanlarının toksik liderliğe ilişkin algıları arasında "mesleki tecrübe" değişkenine göre anlamlı farklılık olmadığı tespit edilmiştir. Yapılan çalışmanın aksine Özer ve arkadaşlarının (2017) çalışmasında mesleki tecrübe değişkenine göre anlamlı farklılık belirlenmiştir.

Araştırmada banka çalışanlarının toksik liderliğe ilişkin algıları arasında "eğitim durumu" değişkenine göre anlamlı farklılık olmadığı tespit edilmiştir.

Araştırmada banka çalışanlarının toksik liderliğe ilişkin algıları arasında "kurumda çalışma süresi" değişkenlerine göre anlamlı farklılık olmadığı tespit edilmiştir. Fakat "kurumda görev alınan pozisyon" değişkenine göre "Çıkarcılık" ve "Toksik Liderlik Genel" boyutları açısından anlamlı farklılık olduğu, diğer boyutlarda ise anlamlı farklılığın olmadığı tespit edilmiştir. Anlamlı farklılığın bulunduğu boyutlarda anlamlı farklılık; kurumda pozisyonu "memur ile üst yetkili"; "yetkili yardımc1-yetkili ile üst yetkili"; "uzman yardımcısı-uzman ile üst yetkili" olanlar arasında olduğu saptanmıştır.

Araştırmaya katılan banka çalışanlarının Örgütsel Bağlllı̆̆a ilişkin algiları "Duygusal Bağlılık" ve "Normatif Bağl1lık" boyutlarında "Katılıyorum", "Devam Bağlllı̆̆1" boyutunda ise "Orta Düzeyde Katılıyorum" seviyesindedir. Araştırmada banka çalışanlarının örgütsel bağlılığa ilişkin verdikleri cevapların genel ortalamasının "Katılıyorum" düzeyinde olduğu belirlenmiştir. Elde edilen bu sonuçlar doğrultusunda banka çalışanlarının örgütsel bağlılıklarının yüksek seviyede olduğu söylenebilir. 
Banka çalışanlarının örgütsel bağlılığa ilişkin algıları arasında "cinsiyet" değişkenine açısından anlamlı farklılığın yalnızca "Devam Bağlılığı" boyutunda olduğu tespit edilmiştir. Cinsiyet değişkenine göre banka çalışanlarının algıları arasında anlamlı farklılığın tespit edildiği "Devam Bağlılığı" boyutunda anlamlı farklılığın kadınların lehine olduğu görülmüştür. Yani kadın çalışanların "Devam Bağlılık” ları erkeklere göre anlamlı oranda yüksektir.

Kadın banka çalışanlarının devam bağlılıklarının erkeklere göre yüksek olmasında örgütte yani bankada çalışmaya kalmaya ihtiyaç duymalarının etkili olduğu söylenebilir. Kadın çalışanların bankada çalıştıkları süre içerisinde elde ettikleri para, statü gibi kazanımları erkeklere göre daha fazla algıladıkları için örgüte olan bağlılıkları daha fazladır. Ayrıca kadın banka çalışanlarının mevcut işlerine alternatif iş olanaklarının az olduğuna inandıkları için mevcut işlerine bağlılıkları daha yüksek olmuş olabilir.

Banka çalışanlarının örgütsel bağlılığa ilişkin algıları arasında "cinsiyet" değişkenine açısından "Duygusal Bağllık, Normatif Bağlllık, Örgütsel Bağlılık Genel" boyutlarında anlamlı farklılık olmadığı tespit edilmiştir. Başka bir ifade ile "Duygusal Bağllık", "Normatif Bağlılık", "Örgütsel Bağllılık Genel" boyutlarında banka çalışanlarının cinsiyet faktörüne göre algilarının birbirine yakın olduğu şeklinde söylenebilir.

Banka çalışanlarının örgütsel bağlılığa ilişkin algıları arasında "medeni durum" değişkenine göre anlamlı farklılık olmadığı tespit edilmiştir. Medeni durum değişkenine göre banka çalışanlarının algıları arasında anlamlı farklılığın tespit edilmediği örgütsel bağlılık ölçeğinde evli olanların ortalamaları incelendiğinde "Duygusal Bağlıllk", bekâr olanların ise "Normatif Bağll11k" boyutunda en yüksek ortalamaların olduğu saptanmıştır.

Banka çalışanlarının örgütsel bağllığa ilişkin algıları arasında "eğitim durumu" değişkenine göre "Normatif Bağlllık" ve "Örgütsel Bağlllık Genel" boyutlarında anlamlı farklılık olduğu tespit edilmiştir. Bulunan anlamlı farklılığın lise-ön lisans mezunları ile lisans mezunları arasında, liseön lisans mezunları ile lisansüstü mezunları arasında olduğu saptanmıştır. Eğitim düzeyi düşük olanların örgütsel bağlllı̆̆ yüksek çıkmıştır. Chughtai ve Zafar (2006, s.40) eğitim düzeyi yükseldiğinde bağlı̆̆ın düştüğünün tespit etmiştir. 
Banka çalışanlarının örgütsel bağl1lığa ilişkin algıları arasında "mesleki tecrübe" değişkenine göre "Duygusal Bağlllık", "Normatif Bağlllık" ve "Örgütsel Bağlılık Genel" boyutlarında anlamlı farklılık olduğu belirlenmiştir. Bulunan anlamlı farklılığın her üç boyutta 10 yıl üzeri mesleki tecrübeye sahip olan banka çalışanları ile 6-10 yıl arası mesleki tecrübeye sahip olan banka çalışanları arasında olduğu saptanmıştır. Ayrıca "Duygusal Bağlılı" boyutunda anlamlı farklılığın 10 yıl üzeri mesleki tecrübeye sahip olan banka çalışanları ile 5 yıl ve altında mesleki tecrübeye sahip olan banka çalışanları arasında olduğu belirlenmiştir.

Bankada görev yapan çalışanların mesleki tecrübelerinin artış göstermesi ile birlikte örgütsel bağlllıklarında bir artış olduğu görülmektedir. $\mathrm{Bu}$ artış mesleki tecrübesi az olan çalışanlar ile anlamlı derecede ayrışmaktadır. Bankacılık geçmişi daha fazla olan çalışanların zaman içerisinde örgüte olan bağlılıkları artış göstermiştir. Yani görev süresinin artışı ile örgütsel bağlılık arasında pozitif bir ilişkinin olduğu söylenebilir. Başka bir ifade ile örgütsel bağlılığı yüksek olan tecrübeli banka çalışanlarının, bankada kalmayı doğru ve ahlaki olduğu algısına sahip olarak çalışmayı sürdürdükleri ileri sürülebilir.

Banka çalışanlarının örgütsel bağlılığa ilişkin algıları arasında "kurumda çalışma süresi" değişkenine göre "Duygusal Bağlllık", "Normatif Bağlllık" ve "Örgütsel Bağlılık Genel" boyutlarında anlamlı farklılık olduğu belirlenmiştir. Bulunan anlamlı farklılığın her üç boyutta 10 yıl üzeri kurumda çalışanlar ile 6-10 yıl ile 5 yıl ve altında aynı kurumda görev yapan banka çalışanları arasında olduğu belirlenmiştir. Kurumda çalışma süresi değişkenine ilişkin araştırma verileri mesleki tecrübe değişkenine göre elde edilen verilerle örtüşmektedir. Sonuçların bu şekilde çıkmasında araştırmanın bir kamu bankasında yapılmış olmasının kamu bankaları arasında geçiş imkânının olmamasından kaynaklı olduğu söylenebilir. Bir kamu bankası çalışanı aynı kurumda başlayıp devam ettiği için mesleki tecrübe ve kurumda çalışma süresi paralel ilerlemektedir. Araştırma sonuçları da bu durumu desteklemiştir.

Örgüt içindeki hizmet süresi, algılanan yönetici desteği, iş-aile iklimi ve iş-aile dengesinin korunması konusunda işgörenlerin desteklenmesi gibi hususlar örgütsel bağlllığı besleyen etkenlerdendir ( $\mathrm{O}^{\prime} \mathrm{Neill}$ vd., 2009, s.26). Ayrıca aynı işletmede çalışma süresi arttıkça, işgörenin elde ettiği edinimleri de çoğalmakta ve bağlılı̆̆1 sürmektedir (Chughtai ve Zafar (2006, s.40). Bu 
kazanımların çoğu zaman hesaba katıldığında; emek ve o güne kadar elde edilen faydaların yitirilmemesi için aynı yerde çalışmaya devam edilebilmektedir (Afşar, 2015, s.52). Bu bağlamda mesleki tecrübe ve kurumda çalışma süresi açısından araştırmada elde edilen süre arttıkça örgütsel bağlllığın arttığı sonucu desteklenmektedir.

Banka çalışanlarının örgütsel bağlılığa ilişkin algıları arasında "kurumdaki pozisyon" değişkenine göre "Duygusal Bağlllık", "Devam Bağlılık" ve "Örgütsel Bağlllık Genel” boyutlarında anlamlı farklılık olduğu belirlenmiştir. Bulunan anlamlı farklılık:

Duygusal Bağlllık, devam bağlllığ1 ve örgütsel bağlllık boyutunda, pozisyonlara göre anlamı farklılıkların olduğu görülmüş̧ür.Anlamlı farklılığın bulunduğu boyutlarda banka içerisinde pozisyonu müdür yardımcısı seviyesinde olanların diğer pozisyonda görev alan çalışanlara göre örgütsel bağlllıkları yüksek çıkmıştır.Bu sonucun oluşmasında üst pozisyonda görev alan banka çalışanlarının gerek ücret gerekse de statü gereksinimlerinin karşılanmış olmasının örgütsel bağlllıklarına pozitif etki ettiği şeklinde yorumlanabilir.

Araştırmada müdür yardımcı pozisyonunda görev yapan banka çalışanlarının örgütsel bağlllıklarının yüksek çımasını kurumdan beklentilerinin karşılanması şeklinde yorumlanmıştır. Bu sonucun tersi bir durum, uzman yardımcısı-uzman pozisyonunda çalışanlardan elde edilen verilerle tespit edilmiştir. Uzman yardımcısı-uzman pozisyonunda görev yapanların eğitim seviyesinin, bulundukları pozisyonun diğer çalışanlara göre yüksek olması beklentilerini arttırdığı ve bu beklentilerin geç veya hiç karşılanmaması durumunda örgütsel bağlılıklarında paralelinde de iş tatminlerinde azalma yaşandığı söylenebilir.

Eğitim durumu değişkeninde "Duygusal ve Devam Bağlllık" boyutlarında; "mesleki tecrübe ve kurumda çalışma süresi" değişkenlerinde devam bağlllığı boyutunda; "kurumdaki pozisyon" değişkeninde normatif bağlılık boyutlarında banka çalışanlarının algıları arasında anlamlı farklılık olmadığı belirlenmiştir. Başka bir ifade ile banka çalışanlarının sayılan değişken ve boyutlarda algılarının birbirine benzer olduğu söylenebilir.

Toksik liderlik ve örgütsel bağlılık arasındaki korelasyona ilişkin veriler incelendiğinde "Normatif Bağlılık-Olumsuz Ruhsal Durum" boyutları arasında anlamlı ilişki bulunamamıştır. Fakat diğer tüm boyutlar arasında negatif yönlü anlamlı ilişki bulunmuştur. Araştırmada “Toksik Liderlik ve 
Örgütsel Bağlllık" arasındaki ilişkinin düzeyine ait veriler incelendiğinde Duygusal Bağlılık" ve "Değer Bilmezlik-Çıkarcılık" arasında orta düzeyde, "Duygusal Bağlllık" ve "Bencillik-Olumsuz Ruhsak Durum" arasında düşük düzeyde ilişki olduğu sonucuna ulaşılmıştır. Örgütsel Bağlllık ölçeğinin "Devam Bağllık-Normatif Bağlılık-Örgütsel Bağlllık Genel" boyutları ile "Toksik Liderlik" ölçeğinin bütün boyutları arasında düşük düzeyde ilişki olduğu araştırmada tespit edilmiştir. Fakat "Örgütsel Bağlllık Genel" ile "Toksik Liderlik" ölçeğinin "Değer Bilmezlik" boyutu arasında orta düzeyde bir ilişki olduğu araştırmada saptanmıştır.

"Değer Bilmezlik", “Çıkarcılık”, "Bencillik", "Olumsuz Ruhsal Durum” ile "Duygusal Bağlllık-Devam Bağlllık-Normatif Bağllık" arasındaki neden sonuç ilişkisi anlamlı bulunmuştur. "Duygusal-Devam-Normatif Bağlllık" düzeyinin belirleyicisi olarak "Değer Bilmezlik, Çıkarcılık, Bencillik, Olumsuz Ruhsal Durum" boyutları ile ilişkisinin zayıf olduğu görülmüştür. Banka çalışanlarının algıladıkları "Değer Bilmezlik" düzeyi "DuygusalDevam-Normatif Bağlılık" düzeyini azaltmaktadır. Banka çalışanlarının algıladıkları "Çıkarcılık, Bencillik ve Olumsuz Ruhsal Durum" düzeyleri, "Duygusal-Devam-Normatif Bağlllık" düzeyini etkilememektedir.

Alatrista ve Arrowsmith (2004) tarafından yapılan araştırmada, çalışanların örgütsel bağlılığını arttırmaya yönelik yönetimsel çabalarının özellikle kamu dışı sektörde çok zor olduğu belirtilmiştir. Zaten zor olan bu çabaların üzerine oluşacak toksik liderlik davranışlarının etkisinin örgütler için azaltılmasının önemi yeterince açıtır. Bu bakımdan özel sektöre yönelik öneriler aşağıda sunulmuştur.

1. Çalışanların örgütsel bağlllık düzeyindeki sorunu önlemek düzeltmekten daha önemlidir. Öncelikle, bankalarda toksik liderlik davranışları gösteren yöneticilerin belirlenmesi ve engellenmesi gerekmektedir.

2. Araştırma neticesinde toksik liderlik davranışlarının örgüte; kalıcı olumsuz etkiler bırakabileceği anlaşılmaktadır. Toksik liderlik boyutlarının işletimsel değişkenlerinin sektörel ve hatta departmana yönelik olarak betimlenmesi adına araştırmalar yaygınlaştırılabilir.

3. "Toksik Liderlik" ve "Örgütsel Bağlllık" kavramlarının birbiri ile olan ilişkisinin ve etkisini derinlemesine incelenebilmesi için araştırma yöntemlerinde çeşitliliğe gidilerek farklı örneklem grupları üzerinde 
nitel ve nicel çalışmalar birlikte yürütülerek karma araştırmalar yapilabilir.

4. Araştırmanın sonuçları kamu bankalarında çalışan personel ve yöneticiler ile sınırlıdır. Bundan dolayı araştırma sonuçlarındaki sınırlılığı aşmak için; özel bankalarda ve katılım bankalarında çalışan personel ile de araştırma yapılarak daha kapsamlı çalışmalar yapılabilir. 


\title{
EXTENDED ABSTRACT
}

\section{Organizational Commitment as an Output of Toxic Leadership \\ Yeşim Eriş - Korhan Arun \\ Namık Kemal University}

\begin{abstract}
Although leadership behaviours are generally similar, there are differences between some leadership practices in terms of domination and pressure. This study aims to investigate the effect of toxic leadership and demographic variables on organizational commitment of bank employees. For this purpose, the level of organizational commitment in a public bank, the level of harmful leadership of managers, their interrelation, and their interrelation were examined empirically in terms of demographic characteristics.

In order to reach the stated aims of the study, the screening model was preferred. The population of the study is composed of employees working in a public bank located in Eastern Anatolia Region. The research sample consisted of 302 bank employees selected from the universe using the "Simple Random Sampling" method.

In order to measure the perception of organizational commitment of bank employees, the 18-item form of Meyer and Allen's revised organizational commitment scale developed by Meyer et al. The original form of the toxic leadership scale, developed by Çelebi et al. (2015), consists of a total of 30 items and four dimensions, namely "self-promotion", "Insignificance", "Negative Mental Status", "Selfishness".

As a result of analyzing the research conducted, it was seen that toxic leadership influenced organizational commitment. Besides, as a result of detailed correlation analysis, it was concluded that toxic leadership behaviours had a negative effect on all organizational commitment dimensions except normative commitment. In the study, the perceptions of the bank employees regarding toxic leadership were found to differ significantly according to the" position in the institution" and in the "Narcissism" and "Toxic Leadership General" dimensions. The position in the institution of the meaningful difference is the officer with the top
\end{abstract}


authority; authorized-competent and highest authorized; It is among the top authorized persons with the expert. The employees' perceptions of organizational commitment differed significantly in terms of gender and marital status; It was determined that there was a consequential difference in general dimension of organizational commitment according to education status, professional experience, working time in institution and position in the institution. In the study, a relevant negative correlation was found between Toxic Leadership and Organizational Commitment. Toxic leadership behaviours decrease organizational commitment in general. However, interestingly, the perception of the duty of bank employees has not been observed to change their behaviour towards not turnover, or not to leave that institution, as a result of the importance of the job. The perceptions of the bank employees involved in the study about toxic leadership are at the level of "I do not agree", with "self-promotion", "selfishness", and "insignificance", and "Moderately Agree" in the "negative mental status" dimension. In the study, it has been determined that the overall average of the responses of the bank employees regarding toxic leadership is at the level of "Disagree". In line with these results, it can be said that the toxic leadership behaviours of bank managers are low. Whether this is due to be a public bank can be investigated in future research. However, we found that there is no significant difference between the perceptions of bank employees about toxic leadership according to the "education level" variable. But it has been determined that there is a significant difference in terms of "self-promotion" and Toxic Leadership according to the "position in the institution" variable.

In the research, the organizational commitment of bank employees working in the position of assistant manager has been interpreted as meeting their expectations from the institution. The opposite of this result is seen by the data obtained from those working in the assistant expert-expert position. It can be said that the level of education of those who work in assistant-expert position increases their expectations that their position is higher than other employees. If these expectations are not met late or at all, job satisfaction also decreases in parallel with their organizational commitment.

In line with the obtained results, it can be said that the organizational commitment of bank employees is at a high level. It was determined that 
there was a significant difference between the perceptions of the Bank employees about organizational commitment in terms of "education status" variable in terms of "Normative Commitment" and "Organizational Commitment-General" dimensions. It is found that the significant difference was found between high school and undergraduate (high school) graduates, and between high school and university graduates. Organizational commitment of those with low education level was high. Nevertheless, it is observed that there is an increase in organizational commitment with the increase of professional experience of the employees working in the bank. This increase diverges significantly with employees with little professional experience. The loyalty of employees with more banking history has increased over time.

According to the perceptions of bank employees, the level of organizational leadership of employees decreases as the level of toxic leadership of manager's increases. In other words, it was found that there was a cause-effect relationship between the two variables.

In the research conducted by Alatrista and Arrowsmith (2004), it was stated that the administrative efforts of the employees to increase their organizational commitment are very difficult, especially in the non-public sector. The importance of reducing the impact of toxic leadership behaviours on these already strenuous efforts for organizations is clear enough. In this regard, recommendations for the private sector are presented below.

It is more important to prevent the problem of employees' organizational commitment than to correct the situation. First, managers that show toxic leadership behaviours in banks should be identified and prevented.

In order to examine the relationship and impact of the concepts of "Toxic Leadership" and "Organizational Commitment" in-depth, mixed research can be conducted by conducting qualitative and quantitative studies together on different sample groups.

\section{Kaynakça / References}

Afşar, S.T. (2015). Impact of the quality of work-life on organizational commitment: A Comparative study on academicians working for state and foundation. Is, Guc: The Journal of Industrial Relations and Human Resources, 17(2), 45-75. 
Alatrista, J. ve Arrowsmith, J. (2004). Managing employee commitment in the not-for-profit sector. Personnel Review, 33(5), 536-548.

Allen, N.J. ve Meyer, J.P. (1990). The measurement and antecedents of affective, continuance and normative commitment to the organization. Journal of Occupational Psychology, 63(1), 1-18.

Aryee, S., Chen, Z. X., Sun, L.-Y., ve Debrah, Y. A. (2007). Antecedents and outcomes of abusive supervision: Test of a trickle-down model. Journal of Applied Psychology, 92(1), 191-201.

Baycan, F.A. (1985). An analysis of several aspects of job satisfaction between diffrent occupational groups. Basılmamış Yüksek Lisans Tezi, Boğaziçi Üniversitesi, Sosyal Bilimler Enstitüsü, Psikoloji Anabilim Dalı, İstanbul.

Bayram, L. (2005). Yönetimde yeni bir paradigma: Örgütsel bağlılık. Sayıştay Dergisi, 59, 125-139.

Bozkurt, Ö. ve Yurt, İ. (2013). Akademisyenlerin örgütsel bağlılık düzeylerini belirlemeye yönelik bir araştırma. Yönetim Bilimleri Dergisi, 11(22), 121139.

Breiger, R. L. (2002). 9. Poststructuralism in organizational studies. In Research in the Sociology of Organizations: Social Structure and Organizations Revisited (Vol.: 19, p.295-305). https://doi.org/10.1016/S0733-558X(02)19009-4

Brown, D. R. (2014). Experiential approach to organization development.

Büyüköztürk, Ş., Çakmak, E.K., Akgün, Ö.E., Karadeniz, Ş. ve Demirel, F. (2012). Bilimsel araştırma yöntemleri. Pegem Akademi Yayınları, Ankara.

Can, A. (2016). SPSS İle bilimsel araştırma sürecinde nicel veri analizi (4.Baskı). Ankara:Pegem Akademi Yayınları,.

Casper, W.J., Harris, C., Taylor-Bianco, A., ve Wayne, J.H. (2011). Work-family conflict, perceived supervisor support and organizational commitment among Brazilian professionals. Journal of Vocational Behavior, 79(3), 640652.

Chang, H.T., Chi, N.W., ve Miao, M.C. (2007). Testing the relationship between three-component organizational/occupational commitment and organizational/occupational turnover intention using a non-recursive model. Journal of Vocational Behavior, 70(2), 352-368.

Chen, Z.X. ve Aryee, S. (2007). Delegation and employee work outcomes: An examination of the cultural context of mediating processes in China. Academy of Management Journal, 50(1), 226-238. 
Chughtai, A.A. ve Zafar, S. (2006). Antecedents and consequences of organizational commitment among Pakistani University teachers. Applied HRM Research, 11(1), 39-64.

Cohen, A. (2007). Commitment before and after: An evaluation and reconceptualization of organizational commitment. Human Resource Management Review, 17(3), 336-354.

Cuskelly, G. ve Boag, A. (2001). Organisational commitment as a predictor of committee member turnover among volunteer sport administrators: Results of a time-lagged study. Sport Management Review, 4(1), 65-86.

Çelebi, N., Güner, H. ve Yıldız, V. (2015). Toksik liderlik ölçeğinin geliştirilmesi. Bartın Üniversitesi Eğitim Fakültesi Dergisi, 4(1), 249-268.

Çetinkaya, H. (2017). Okul yöneticilerinin toksik (zehirli) liderlik davranışları ile öğretmenlerin tükenmişlik düzeyleri arasındaki ilişki. Yayımlanmamış yüksek lisans tezi, Pamukkale Üniversitesi, Denizli.

Chiaburu, D. S., Oh, I.-S., Berry, C. M., Li, N., ve Gardner, R. G. (2011). The fivefactor model of personality traits and organizational citizenship behaviors: A meta-analysis. Journal of Applied Psychology, 96(6), 11401166. https://doi.org/10/fnfd2q

Choi, D., Oh, I.-S., ve Colbert, A. E. (2015). Understanding organizational commitment: A meta-analytic examination of the roles of the five-factor model of personality and culture. Journal of Applied Psychology, 100(5), 1542. https://doi.org/10/gckfrp

Colquitt, J. A., Conlon, D. E., Wesson, M. J., Porter, C. O. L. H., ve Ng, K. Y. (2001). Justice at the millennium: A meta-analytic review of 25 years of organizational justice research. Journal of Applied Psychology, 86(3), 425445. https://doi.org/10/cpmf2x

Davis, A. L., \& Rothstein, H. R. (2006). The effects of the perceived behavioral integrity of managers on employee attitudes: A meta-analysis. Journal of Business Ethics, 67(4), 407-419. https://doi.org/10/fjq8fs

Demirel, N. (2015). Öğretmen algılarına göre okul müdürlerinin toksik liderlik davranışları ile öğretmenlerin örgütsel sinizm tutumları arasindaki ilişki:Gaziantep Şehitkâmil ilçesi örneği. Yayımlanmamış yüksek lisans tezi, Kahramanmaraş Sütçü İmam Üniversitesi, Gaziantep.

Dirks, K. T., ve Ferrin, D. L. (2002). Trust in leadership: Meta-analytic findings and implications for research and practice. Journal of Applied Psychology, 87(4), 611-628. https://doi.org/10/fvw2m3 
Dobbs, J.M. (2014). The relationship between perceived toxic leadership styles, leader effectiveness, and organizational cynicism.University of San Diego, School of Leadership and Education Sciences, Proquest.

Eğilmezkol, G. (2011). Çalışma yaşamında örgütsel adalet ve örgütsel bağhllık: Bir kamu bankasındaki çalısanlarm örgütsel adalet ve örgütsel bağhllk algılayışlarının analizine yönelik bir çalışma. Basılmamış Yüksek Lisans Tezi, Gazi Üniversitesi, Sosyal Bilimler Enstitüsü, İşletme Anabilim Dalı Genel İşletme Bilim Dalı, Ankara.

Erdem, H., Gökmen, Y., \& Türen, U. (2015). Psikolojik sermayenin örgütsel özdeşleşme üzerine etkisinde algilanan örgütsel desteğin aracılık rolü. İşletme Araştırmaları Dergisi, 7(2), 38-62.

Ferris, G.R., Zinko, R., Brouer, R.L., Buckley, M.R., ve Harvey, M.G. (2007). Strategic bullying as a supplementary, balanced perspective on destructive leadership. The Leadership Quarterly, 18(3), 195-206.

Futterman, S. (2004). When you work for a bully: assessing your options and taking action (1st ed). Montvale, NJ : Chicago, Il: Croce Pub. Group ; distributed by Independent Publishers Group.

Gregersen, H. B. (1993). Multiple commitments at work and extrarole behavior during three stages of organizational tenure. Journal of Business Research, 26(1), 31-47. https://doi.org/10/bqmq6q

Gül, H. (2002). Örgütsel bağlılık yaklaşımlarının mukayesesi ve değerlendirmesi. Ege Akademik Bakış, 2(1), 37-56.

Harvey, M., Treadway, D., ve Heames, J. (2007). The occurrence of bullying in global organizations: A model and issues associated with social/emotional contagion. Journal of Applied Social Psychology, 37(11), 2576-2599.

Hirschfeld, R.R. (2000). Does revising the instrinsic and extrinsic subscales of the Minnesota satisfaction questionnaire short form make a difference?, Educational \& Psychological Measurement, 60(2), 255-270.

Holt, R., ve Sandberg, J. (2011). Phenomenology and organization theory. In Philosophy and organization theory, 32, 215-249.

Iverson, R.D. ve Deery, M. (1997). Turnover culture in the hospitality industry. Human Resource Management Journal, 7(4), 71-82.

Incir, G. (1990) Çalışanların iş doyumu üzerine bir inceleme. Ankara:Milli Prodüktivite Merkezi Yayınları. 
İzgüden, D., Eroymak, S. ve Erdem, R. (2016). Sağlık kurumlarında görülen toksik liderlik davranışları: Bir üniversite hastanesi örneği. Balkan Sosyal Bilimler Dergisi, 5(9), 262-276.

Kalaycı, Ş. (2010). SPSS uygulamalı çok değişkenli istatistik teknikleri (9.Baskı), Ankara:Asil Yayıncllk,--.

Karasar, N. (2016). Bilimsel araştırma yöntemi. Ankara:Nobel Yayınları.

Kim, W.G., Leong, J.K., ve Lee, Y.K. (2005). Effect of service orientation on job satisfaction, organizational commitment, and intention of leaving in a casual dining Chain Restaurant. International Journal of Hospitality Management, 24(2), 171-193.

Kramer, R. M., ve Gavrieli, D. (2005). The perception of conspiracy: Leader paranoia as adaptive cognition. (D. M. Messick ve R. M. Kramer Eds.), The psychology of leadership: new perspectives and research içinde ( s. 241274). Mahwah, N.J: L. Erlbaum Associates.

Lipman-Blumen, J. (2010). Toxic leadership. (Ed. Richard A. Couto) Political and Civic Leadership: A Reference Handbook, Sage Publication California, ABD.

Mathieu, J. E., ve Zajac, D. M. (1990). A review and meta-analysis of the antecedents, correlates, and consequences of organizational commitment. Psychological Bulletin, 108(2), 171-194.

Mowday, R. T., Porter, L. W., ve Steers, R. M. (1982). Employee-organization linkages: The psychology of commitment, absenteeism, and turnover. New York: Academic Press.

Meyer, J.P., Allen, N.J., ve Smith, C. (1993). Commitment to Occupations: Extension and Test of a Three-Component Conceptualization, Journal of Applied Psychology, 78(4), 538-551.

Miao, Q., Newman, A., Sun, Y., ve Xu, L. (2013). What factors influence the organizational commitment of public sector employees in China? The Role of extrinsic, intrinsic and social rewards. The International Journal of Human Resource Management, 24(17), 3262-3280.

Morrow, P. C. (2011). Managing organizational commitment: Insights from longitudinal research. Journal of Vocational Behavior, 79(1), 18-35.

Okun, O. (2020). The Positive Face of Human Capital, Psychological Capital, and Well-Being. 10.4018/978-1-7998-2509-8.

O'Neill, J.W., Harrison, M.M., Cleveland, J., Almeida, D., Stawski, R., ve Crouter, A.C. (2009). Work-family climate, organizational commitment, and turnover: Multilevel contagion effects of leaders. Journal of Vocational Behavior, 74(1), 18-29. 
Özkalp, E. ve Kırel, A.Ç. (1996). Örgütsel davranış. Eskişehir:Anadolu Üniversitesi Yayınları.

Özaydın, M.M. ve Özdemir, Ö. (2014). Çalışanların bireysel özelliklerinin iş tatmini üzerindeki etkileri: Bir kamu bankası örneği. İşletme Araştırmaları Dergisi, 6(1), 251-281.

Özer, Ö., Uğurluoğlu, Ö., Kahraman, G. ve Avc1, K. (2017). A study on toxic leadership perceptions of healthcare workers. Global Business and Management Research: An International Journal, 9(1), 12-23.

Öztürk, A. Y. (2007). Ortaöğretim kimya öğretmenlerinin iş tatmini. Basılmamış Yüksek Lisans Tezi, Yeditepe Üniversitesi Sosyal Bilimler Enstitüsü, İstanbul.

Paunonen, S.V., Lönnqvist, J.E., Verkasalo, M., Leikas, S., ve Nissinen, V. (2006). Narcissism and emergent leadership in military cadets. The Leadership Quarterly, 17(5), 475-486.

Raghunathan, B., Raghunathan, T.S., ve Tu, Q. (1998). An empirical analysis of the organizational commitment of information systems executives. Omega, 26(5), 569-580.

Rhoades, L., ve Eisenberger, R. (2002). Perceived organizational support: a review of the literature. Journal of Applied Psychology, 87(4), 698.

Salleh, R., Nair, M.S., ve Harun, H. (2012). Job satisfaction, organizational commitment, and turnover intention: A case study on employees of a retail company in Malaysia. International Journal of Social, Education, Economics and Management Engineering, 6(12), 702-709.

Schmidt, A.A. (2008). Development and validation of the toxic leadership scale. Unpublished Master Theses, Faculty of the Graduate School of the University of Maryland, ABD.

Şimşek, M.Ş. (2008). Yönetim ve organizasyon, Konya:Adım Yayınları.

Tabachnick, B.G. ve Fidell, L.S. (2013). Using multivariate statistics (6.edition). Pearson Education, ABD.

Tepper, B.J. (2007). Abusive supervision in work organizations: Review, Synthesis, And research agenda. Journal Of Management, 33(3), 261-289.

Tubbs, S. L. (2012). A systems approach to small group interaction (11th ed). New York: McGraw-Hill Humanities/Social Sciences/Languages.

Vreja, L.O., Balan, S., ve Bosca, L.C. (2016). An evolutionary perspective on toxic leadership. Management and Economics Review, 1(2), 217-228. 
Wong, C.S., Wong, Y.T., Hui, C., ve Law, K.S. (2001). The significant role of chinese employees' organizational commitment: Implications for managing employees in Chinese Societies. Journal of World Business, 36(3), 326-340.

Williams, C.D.F. (2005). Toxic leadership in the US Army, USA:Army War Coll Carlısle Barracks Pa.

Wilson-Starks, K.Y. (2003). Toxic leadership. Transleadership, Inc. 719-534, 26.03.2019 tarihinde www.transleadership.com adresinden erişilmiştir.

Woestman, D.S., ve Wasonga, T.A. (2015). Destructive leadership behaviors and workplace attitudes in schools, NASSP Bulletin, 99(2), 147-163.

Wright, E. E. (2015). Toxic management styles: The problem, prevention, and cure. Trengaws Publishing.

Yang, M.L. (2012). Transformational leadership and Taiwanese public relations practitioners' job satisfaction and organizational commitment. Social Behavior and Personality: an international journal, 40(1), 31-46.

Yukl, G. (2013). Leadership in organizations . New Jersey Pearson Educations Inc.

\section{Kaynakça Bilgisi / Citation Information}

Eriş, Y. ve Arun, K. (2020). Toksik liderliğin bir çıktısı olarak örgütsel bağlılık. OPUS-Uluslararası Toplum Araştırmaları Dergisi, 15(24), 2764-2804. DOI: 10.26466/opus.599311 